\title{
Even Some International Law is Local: Implementation of Treaties through Subnational Mechanisms
}

Charlotte Ku

Texas A\&M University School of Law, cku@law.tamu.edu

William $\mathrm{H}$. Henning

Texas A\&M University School of Law, bhenning@law.tamu.edu

David P. Stewart

Georgetown University Law Center, stewartd@law.georgetown.edu

Paul F. Diehl

University of Texas at Dallas

Follow this and additional works at: https://scholarship.law.tamu.edu/facscholar

Part of the Constitutional Law Commons, International Law Commons, and the Transnational Law Commons

\section{Recommended Citation}

Charlotte Ku, William H. Henning, David P. Stewart \& Paul F. Diehl, Even Some International Law is Local: Implementation of Treaties through Subnational Mechanisms, 60 Va. J. Int'I L. 101 (2019).

Available at: https://scholarship.law.tamu.edu/facscholar/1375

This Article is brought to you for free and open access by Texas A\&M Law Scholarship. It has been accepted for inclusion in Faculty Scholarship by an authorized administrator of Texas A\&M Law Scholarship. For more information, please contact aretteen@law.tamu.edu. 


\title{
ARTICLE \\ EVEN SOME INTERNATIONAL LAW IS LOCAL: IMPLEMENTATION OF TREATIES THROUGH SUBNATIONAL MECHANISMS
}

\author{
Charlotte Ku, William H. Henning, David P. Stewart, and Paul F. \\ Diehl $^{*}$
}

Multilateral treaties today increasingly touch on subjects where there is existing domestic law in the United States. In the U.S. federal system, this domestic law may not be national law, but law of the constituent U.S. States. However, in light of Article $V I$ of the U.S. Constitution, treaties in their domestic application unavoidably federalize the subjects they address. The most sensitive issues arise when a treaty focuses on matters primarily or exclusively dealt with in the United States at the State or local level. Although U.S. practice allows for some flexibility to accommodate State/local interests, the federal government reserves the authority to compel compliance in case a State adopts a rule contrary to an international agreement which would place the United States in breach of its international obligations. This Article examines the role constituent States in the U.S. system can play in treaty implementation. The subject is of interest to determine the conditions under which State authority might be considered for undertaking and implementing U.S. treaty obligations. This Article examines the processes under which subnational implementation of international treaties can be brought to fruition and when it fails; when there are Uniform Law Commission products and drafting expertise available to facilitate implementation at the State level; and whether these approaches might enhance the ability of the United States to implement treaty obligations.

* Charlotte $\mathrm{Ku}$ is Professor of Law; Associate Dean for Global Programs and Graduate Studies; Co-Convenor of the Global and Comparative Law Program, Texas A\&M University School of Law; Ph.D., M.A.L.D., M.A., Fletcher School of Law and Diplomacy, Tufts University; B.A., School of International Service, American University.

William H. Henning is Executive Professor of Law, Texas A\&M University School of Law; LL.M., University of Illinois College of Law; J.D., University of Tennessee College of Law; B.A., University of Tennessee at Chattanooga.

David P. Stewart is Professor from Practice; Co-Director, Global Law Scholars Program; Director, Center on Transnational Business and the Law, Georgetown University Law Center; LL.M., New York University; J.D., M.A., Yale; B.A. Princeton.

Paul F. Diehl is Ashbel Smith Professor of Political Science; Associate Provost and Director, Center for Teaching and Learning, University of Texas, Dallas; Ph.D., M.A., University of Michigan; B.A., Canisius College.

The authors gratefully acknowledge the research assistance of Adria Stallcup, J.D. '18, Texas A\&M University School of Law and Isaac Olson, J.D. '19, Texas A\&M University School of Law. 
I. SITUATING THE STUDY

II. WHY SUBNATIONAL IMPLEMENTATION OF INTERNATIONAL

AGREEMENTS?

III. THEORETICAL FRAMEWORK: UNDERSTANDING SUBNATIONAL

IMPLEMENTATION

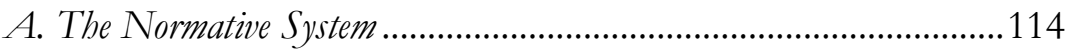

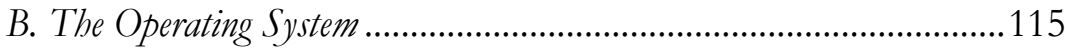

C. Gaps in the Operating System ............................................................115

IV. THE UNIFORM LAW COMMISSION AND SUBNATIONAL

IMPLEMENTATION IN THE UNITED STATES ........................................118

A. The ULC Development and Enactment Process................................124

B. ULC Participation in Treaty Negotiation and Domestic Implementation

C. The United States and Analogues in Other Federal Systems .............133

V. SuCCESS AND FAILURE IN SUBNATIONAL IMPLEMENTATION....139

A. The Hague Convention on the International Recovery of Child Support and Other Forms of Family Maintenance ......................................................140

B. The W ashington Convention of 1973 (Recognition of International

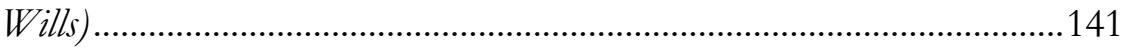

C. Lessons for Successful Subnational Implementation of Treaties............142

VI. ARE SELF-EXECUTING TREATIES THE SOLUTION? .......................143

A. Convention on the Assignment of Receivables in International Trade.144

B. Convention on the International Sale of Goods .................................. 147

C. Self-Executing Treaties and Their Limitations .................................149

VII. CONCLUSIONS AND IMPLICATIONS..............................................150 


\section{SituATING THE STUDY}

Due to its federal structure, the United States increasingly confronts an issue not faced by most other countries, particularly those with unitary structures in which the central government possesses all legislative (or law-making) power: how to implement its treaty obligations effectively and in accordance with its government principles of federalism. The issue may not be readily apparent to those lacking a clear understanding of the U.S. constitutional structure. It is deeply consequential, however, and in recent years has generated a new (and somewhat debatable) phenomenon: implementation of U.S. treaty obligations by subnational (i.e., State and local) mechanisms.

In the United States, the treaty power is reserved exclusively to the federal government. Treaties are "made" by the President, by and with the consent of the Senate. ${ }^{1}$ The constituent States are in fact expressly prohibited by the Constitution from entering into "any Treaty, Alliance, or Confederation" and "without the Consent of Congress . . . into any Agreement or Compact with another State, or with a foreign Power."2 In its famous Missouri v. Holland decision, the U.S. Supreme Court observed that the Constitution expressly delegates the entirety of the treaty power to the federal government, to the exclusion of the States. ${ }^{3}$

"Treaties" 4 are thus creatures of the national government; they constitute (and are governed by) federal law. Under Article VI, clause 2 of the Constitution, once they have been ratified and brought into force, they form part of the "supreme law of the land," equivalent to federal statutes, binding on the States and pre-empting contrary State law ("the Judges in every State shall be bound thereby, any Thing in the Constitution or Laws of any State to the contrary notwithstanding"). 5

Although it is generally agreed today that the Founders must have intended treaties to be directly effective, at least with respect to the

\footnotetext{
1. U.S. CONST. art. II, $₫ 2$, cl. 2.

2. Id. cl. 1-3.

3. 252 U.S. 416, 435 (1920).

4. For present purposes, the term "treaty" is used in its domestic (Article II) sense, and not in the broader context of the Vienna Convention on the Law of Treaties, which would include "executive agreements" and other types of written international undertakings between states and governed by international law.

5. U.S. CONST. art. VI, cl. 2. One of the main reasons the second clause of Article VI was included in the Constitution was the failure of the "States" under the Articles of Confederation to give effect to obligations of the new United States under the 1783 Treaty of Paris, which inter alia obliged the country to recognize the lawful contracted debts of the Loyalists (the U.S. agreed to "earnestly recommend" to state legislatures that they recognize the rightful owners of all confiscated lands and to "provide for the restitution of all estates, rights, and properties, which have been confiscated belonging to real British subjects").
} 
constituent States (their governments, legislatures, and courts), ${ }^{6}$ the U.S. Supreme Court added a major complication in a pair of decisions in the early 19th century by distinguishing between treaties that are "selfexecuting" (meaning directly applicable in all courts, including with regard to the resolution of private disputes) and those that are not self-executing (meaning that to be effective and enforceable in domestic law they require federal implementing legislation). ${ }^{7}$

Increasingly, treaties have addressed issues on which a substantial body of domestic law already exists (in the form of constitutional provisions and doctrine, enacted State and federal legislation, and copious judicial decisions). Indeed, multilateral treaties today rarely address subjects where there is no domestic law. In the U.S. federal system, the relevant domestic law may not be federal (national) but rather law of the several constituent States. ${ }^{8}$ Because of a strong political preference, especially in the U.S. Congress, to resolve any differences between existing law and the treaty obligations by means of enacted legislation (as opposed to direct application of the treaty itself), the practice has emerged of ratifying such treaties on a non-self-executing basis, leaving implementation to the legislature. In addition, the Senate can condition its approval with "reservations" to those parts of the treaties that clearly conflict with constitutional provisions (in particular, the protections of the Bill of Rights) or existing legislative provisions that are clearly inconsistent with the relevant treaty obligations. Some reservations contain the caveat that the reservation could be removed if and when the conflict had been resolved through subsequent legislation, although this is not an option for constitutional conflicts.

In an effort to mitigate the concerns raised by federalization, various approaches to treaty implementation have been adopted. When the treaty touches on a subject that clearly falls within the federal purview (such as the regulation of civil aviation, as was the case with the 1929 Warsaw Convention), implementation by either self-execution or through

6. Ware v. Hylton, 3 U.S. (3 Dall.) 199 (1796) (Chase, J.) ("A treaty cannot be the supreme law of the land, that is of all the United States, if any act of a state legislature can stand in its way."); $c f$. Carlos Vázquez, The Four Doctrines of Self-Executing Treaties, 89 AM J. INT’L L. 695, 698-99 (1995) ("The history of the Supremacy Clause thus shows that its purpose was to avert violations of treaties attributable to the United States, and that the Founders sought to accomplish this goal by making treaties enforceable in the courts at the behest of affected individuals without the need for additional legislative action, either state or federal."); John Quigley, Treaty-Based Rights and Remedies of Individuals, 99 COLUM. L. REV. 1082, 1087-1102 (1992) (same).

7. United States v. Percheman, 32 U.S. (7 Pet.) 51, 89 (1833); Foster v. Neilson, 27 U.S. (2 Pet.) 253, 314 (1827).

8. David P. Stewart, Recent Trends in U.S. Treaty Implementation, in SuPREME LAW OF THE LAND?: DEBATING THE CONTEMPORARY EFFECTS OF TREATIES WITHIN THE UNITED STATES LEGAI SYSTEM 234 (Gregory H. Fox, Paul R. Dubinsky \& Brad R. Roth eds., 2017). 
legislation does not raise the issue.? However, in some instances, multilateral treaties have been adopted on a self-executing basis even though their implementation would also necessarily implicate, preempt or impact State law and enforcement to some degree, for example, the Convention on the International Sale of Goods ("CISG") and the Vienna Convention on Consular Relations (both of which of course rest on strong federal authority - regulation of foreign commerce in the one case, and foreign relations in the other). In these cases, the treaties were adopted as self-executing as they clearly implicate international interests properly regulated under the treaty power. Nevertheless, some of these treaties have worked better in practice than others.

The most sensitive issues arise when the treaty in question focuses on matters primarily or exclusively dealt with at the State or local level. In a few such instances, the treaties have been adopted on the basis that they will be implemented through State law (either legislation or other governmental action or litigation). U.S. practice has shown some flexibility in order to accommodate State or local interests (and to rely on State or local law and procedural mechanisms to give effect to the treaty requirements) while also implementing important international interests. In such cases, however, it has been standard practice for the federal government to include some type of "fallback" mechanism reserving to the federal executive the necessary authority to compel compliance in the event a State adopts a contrary rule. Such a provision is necessary to ensure that the United States does not fail to comply with its international treaty obligations. ${ }^{10}$

That fundamental concern explains why the federal government has not been prepared (to date, at any rate) to rely entirely on enforcement through State or local implementation. ${ }^{11}$ On a few occasions, however, the executive branch has adopted some form of joint implementation, involving "parallel" measures to give effect to the treaty at both State and federal levels (with the necessary "fallback" safeguards). These occasions have involved subjects that normally fall within the purview of the States rather than the federal government.

9. Convention for the Unification of Certain Rules Relating to International Transportation by Air, Oct. 12, 1929, 49 Stat. 3000 .

10. The international law rule is that a state may not excuse or justify its failure to carry out its international treaty obligations on the basis that its internal (domestic) law is inadequate or prevents it from complying. See Vienna Convention on the Law of Treaties art. 27, May 23, 1969, 1155 U.N.T.S. 331.

11. The Hague Convention on the International Recovery of Family Maintenance and Other Forms of Child Support comes close, with the substantive provisions of the Convention set forth in the Uniform Interstate Family Support Act, adopted by every State, and federal involvement (beyond ratification) limited to legislation conditioning federal support for child support collection efforts on enactment of the Uniform Act. 
As the international community increasingly addresses (and adopts instruments concerning) matters that in the United States are typically regulated by the States rather than the federal government, these issues become more sensitive for the United States. Must treaties always and inevitably "federalize" the subjects they deal with? When and how can the federal government acquiesce in treaty implementation at the State and local level without unduly risking international liability in the event of non- compliance? More topically, when can States and local governments "adopt" international obligations even though the federal government has not ratified those treaties or otherwise accepted their obligations as binding? If so, what are the implications for the United States at the international level?

This Article examines these issues from both the political science and legal perspectives. The legal academic literature on the topic of subnational treaty implementation (particularly in the field of human rights) has grown. ${ }^{12}$ Yet the evidentiary record on State and local implementation of treaties is spotty, and there is room for careful empirical research and documentation describing the extent and contours of this phenomenon; on this basis, doctrinal conclusions can be drawn and recommendations made. Separately, a considerable body of literature

12. See, e.g., Thalia González, From Global to Local: Domestic Human Rights Norms in Theory and Practice, 59 How. L.J. 373, 378-80 (2016) (arguing scholarship would greatly benefit from new studies that embrace on-the-ground specificity in order to better understand how human rights ideas translate themselves into behavior at subnational and national levels); Risa E. Kaufman, "By Some Other Means": Considering the Executive's Role in Fostering Subnational Human Rights Compliance, 33 CARDOZO L. REV. 1971, 1978-80 (2012) (arguing the federal executive can play a greater role in fostering compliance with human rights treaties at the state and local level); Johanna Kalb, The Persistence of Dualism in Human Rights Treaty Implementation, 30 YALE L. \& POL'Y REV. 71, 73-74 (2011) (identifying strategies for promoting broader subnational participation in implementing the ratified human rights instruments and for engaging states and cities with the United States' international obligations); Gaylynn Burroughs, More Than An Incidental Effect on Foreign Affairs: Implementation of Human Rights by State and Local Governments, 30 N.Y.U. REV. L. \& SOC. CHANGE 411, 415 (2006) (arguing constitutional jurisprudence should develop to allow state and local governments to enact both inward- and outward-looking human rights legislation); Lesley Wexler, Take The Long Way Home: Sub-Federal Integration of Unratified and Non-Self-Executing Treaty Law, 28 MICH. J. INT'L L. 1, 5 (2006) (examining how sub-federal actors may undertake a treaty integrating role even as the federal government ignores or abandons the particular treaty); Catherine Powell, Dialogic Federalism: Constitutional Possibilities for Incorporation of Human Rights Law in the United States, 150 U. PA. L. REV. 245, 249-51 (2001) (proposing an intergovernmental approach to the allocation of authority between federal and sub-federal systems in the implementation of international human rights law). But see Margaret E. McGuinness, Treaties, Federalism, and the Contested Legacy of Missouri v. Holland, in SuPREME LAW OF THE LAND? DEBATING THE CONTEMPORARY EFFECTS OF TREATIES WiTHIN THE United States Legal System 179 (Gregory H. Fox, Paul R. Dubinsky \& Brad R. Roth eds., 2017) (examining the effect of federalism on the making and enforcement of treaties in the United States); Noha Shawki, Book Review, 72 J. POL. 1259 (2010) (discussing a political-science orientation). 
exists on subnational activity in international law, examining issues of legal pluralism, regulatory coordination, and horizontal federalism. ${ }^{13}$

The study of how domestic legal institutions and processes interact with international law and specifically treaty law has produced a rich interdisciplinary literature that draws on social science research methods. Studies to understand how human rights treaties work in various political and legal systems paved the way. ${ }^{14}$ These studies added domestic institutional and political dimensions to the earlier and more traditional focus on how international law is treated in national constitutions. ${ }^{15}$

Studying how domestic politics, processes, and institutions receive and implement international law has also brought us closer to those who are responsible for discharging these obligations. The increased need to create and to adopt international treaties governing areas that were primarily domestic grows out of recognition that a common approach is desirable to handle the volume of matters and number of approaches in specific private and commercial transactions around the world. ${ }^{16}$

The focus of this Article is on the role that constituent States in the U.S. system play in treaty implementation through their legislative authority and otherwise. The subject is of interest to determine the conditions under which State interests and authority might most appropriately be taken into consideration for implementing U.S. treaty obligations. When international law tracks existing State law and practice, domestic U.S. implementation can be facilitated. We examine the advantages of relying on existing law or existing State administrative structures (e.g., courts) to implement international treaty obligations.

13. See, e.g., Hari M. Osofsky, Rethinking the Geography of Local Climate Action: Multi-Level Network Participation in Metropolitan Regions, 2015 UTAH L. REV. 173, 176-77 (considering how the multilevel climate network participation could be more effective in encouraging additional local action); Hari M. Osofsky, Diagonal Federalism and Climate Change Implications for the Obama Administration, 62 ALA. L. REV. 237, 241-43 (2011) (proposing greater attention be given to the "diagonal" quality of an administration's regulatory interactions); Robert B. Ahdieh, When Subnational Meets International: The Politics and Place of City, State, and Province in the World, 102 AM. SOC'Y INT'L L. PROC. 339, 340 (2008); Judith Resnik, The Internationalism of American Federalism: Missouri and Holland, 73 MO. L. REV. 1105, 1133-34 (2008) (examining horizontal federalism); Robert B. Ahdieh, From Federalism to Intersystemic Governance: The Changing Nature of Modern Jurisdiction, 57 EMORY L.J. 1, 4-5 (2007) (attempting to systematize the exploration of cross-jurisdictional engagement).

14. See, e.g., BETH A. SimMONS, MOBILIZING FOR HUMAN RigHTS: INTERNATIONAL LAW IN DOMESTIC POLITICS (Cambridge University Press, 2012) (exploring why domestic entities commit to and comply with international human rights treaties); Emilia Justyna Powell \& Jeffrey K. Staton, Domestic Judicial Institutions and Human Rights Treaty Violations, 53 INT'L STUD. Q. 149 (2009) (arguing that the effectiveness of the domestic judiciary influences the way states implement treaties).

15. See generally Tom Ginsburg, Svitlana Chernykh, \& Zachary Elkins,

Commitment and Diffusion: How and Why National Constitutions Incorporate International Law, 2008 U. ILL. L. REV. 201 (2008) (describing international law on the constitutional level).

16. Conventions, Protocols, and Principles, Hague CONF. PRIV. INT'L L., https://www.hcch.net/en/instruments/conventions (last visited Dec. 25, 2019) (listing treaties since 1951). 
Using existing legal and political infrastructures to carry out international obligations is likely to be less costly and disruptive than creating new and separate governing systems to support specific international legal obligations. ${ }^{17}$ The purpose of this Article is to understand when State legislation and other collective State action might most appropriately play a role in discharging this function. It examines the processes under which subnational implementation of international treaties occurs with the goal of identifying the conditions under which such an approach can be successful. Accordingly, we examine situations that have achieved success as well as ones that proved incomplete or failed.

We begin, however, with a discussion of the broad framework under which subnational implementation of international law occurs. This discussion involves a brief look at so-called normative and operating systems in international law, with the former representing the prescriptive elements that regulate behavior and the latter addressing the institutions and process of implementation. A gap is created when the operating system, through its international or domestic institutions and processes, is unable to implement or give effect to an international obligation (a part of the normative system). ${ }^{18}$ We consider if subnational implementation in the United States is a way to narrow this gap for the United States thereby enabling more international obligations to be carried out and to have their intended impact. We then move to a description of subnational implementation in the United States and a brief elucidation of similar situations in other countries, indicating the U.S. context is not suigeneris. We end with some conclusions on how best to engage States in the treaty process to provide the level of State participation that would allow for greater U.S. participation in multilateral treaties without federalizing the subject area.

\section{Why SUBNATIONAL IMPLEMENTATION OF INTERNATIONAL AGREEMENTS?}

Some areas of international agreement and commitment obviously concern critical aspects of international relations that, in the U.S. system, fall exclusively within national competence. Examples include matters relating to national security such as arms control and the waging of war,

17. In either case, the solution would need to comply with the provisions of Article VI, cl. 2 of the U.S. Constitution and ensure that the federal government could carry out its constitutional (and international) responsibilities for treaty-making, implementation, and compliance. See U.S. CONST. ART. VI, CL. 2.

18. See generally PAul F. Diehl \& CharlotTe Ku, The DyNAmics OF INTERNATIONAL LAW (2010). 
international trade, and diplomatic relations including the recognition of foreign states and governments. Increasingly, however, international legal obligations are likely to require performance or implicate the existing law at the subnational or local level — for instance, issues related to enforcement of child custody and support orders issued by foreign governments, foreign requests for information relevant to proceedings in foreign courts, and the like.

One critical measurement is the degree to which the international obligation is or is not implemented effectively. It cannot be assumed, for example, that direct implementation (i.e., through self-execution as federal law) is necessarily "better" or more effective than indirect implementation through federal legislation or by State law.

Consider, for example, the complaints brought against the United States for its failure to comply effectively with its obligations under the Vienna Convention on Consular Relations. ${ }^{19}$ Article 36 of the Convention states that

[T] he competent authorities of the receiving State shall, without delay, inform the consular post of the sending State if, within its consular district, a national of that State is arrested or committed to prison or to custody pending trial or is detained in any other manner. Any communication addressed to the consular post by the person arrested, in prison, custody or detention shall be forwarded by the said authorities without delay ....20

When ratified in 1969, the treaty was deemed self-executing and thus became directly applicable throughout the United States. In several notorious instances, however, foreign nationals were arrested by local authorities but not advised of their rights under the Vienna Convention, and in consequence the United States was held in breach of its international obligations.

Since 1997, six capital punishment cases involving the failure to comply with Article 36 were appealed to federal courts after the defendants had exhausted their remedies at the State level, and noncompliance was one among several issues in twenty-one other cases. ${ }^{21}$ Three cases resulted in the United States being brought before the International Court of Justice ("ICJ") for its failure to carry out its treaty obligations as stated in Article 36. In 1998, Paraguay instituted proceedings against the United States contending that the

19. See, e.g., Medellín v. Texas, 552 U.S. 491 (2008); Republic of Paraguay v. Allen, 134 F.3d 622, 625-26 (4th Cir. 1998).

20. Vienna Convention on Consular Relations art. 36(1)(b), Apr. 24, 1963, 21 U.S.T. 77.

21. Isaac Olson, Vienna Convention Death Appeals Cases: 1997 to Present (Sept. 15, 2018) (unpublished manuscript) (on file with author). 
Commonwealth of Virginia had detained, tried and convicted a Paraguayan national, Angel Francisco Breard, of murder and attempted rape and sentenced him to death, all without advising him of his right to consular assistance or notifying Paraguayan consular officials.22 Paraguay sought interim measures to prevent the execution of its national. Nevertheless, Breard was executed by the Commonwealth of Virginia on April 15, 1998.

In the case of José Medellín, a Mexican national who confessed to the 1993 gang rape and murder of two teenage girls in Houston, Texas, local authorities failed to inform the Mexican consulate of his arrest or apprise Mr. Medellín of his rights to have consular assistance while he was in custody. In 2003, Mexico brought suit against the United States in the International Court of Justice claiming the United States to be in violation of its obligations under the Vienna Convention on Consular Relations. In 2004, the ICJ found the United States in violation of its treaty obligations vis-à-vis Mexico. The ICJ determined that the "appropriate reparation in this case consists in the obligation of the United States of America to provide, by means of its own choosing, review and reconsideration of the convictions and sentences of the Mexican nationals." 23 In his final appeal to the U.S. Supreme Court, Mr. Medellín sought to enforce the ICJ judgment, arguing that the United States was legally bound to comply with it. ${ }^{24}$

The U.S. Supreme Court, however, determined that judgments of the International Court of Justice are not directly applicable as domestic law in the United States. ${ }^{25}$ Neither the Optional Protocol to the Vienna Convention (which permitted the Court to hear the case) nor the U.N. Charter Article 94 (which obligated the United States to comply with the ICJ's judgment) are directly applicable ("self-executing") as a matter of U.S. law. Even more importantly, the U.S. Supreme Court said that the President alone could not make them "self-executing." 26 In this instance, although there is a clear treaty obligation, the practical effect of making the treaty 'non-self-executing' is to render it unenforceable in federal court. Consequently, foreigners denied the benefits of a treaty by State authorities would have no remedy.

Moreover, attempts to "federalize" ordinary policing by national legislation have been met with reluctance by federal authorities and strong opposition by States. Proposed federal legislation was therefore never

22. Allen, 134 F.3d at 622.

23. Avena and Other Mexican Nationals (Mex. v. U.S.), Judgment, 2004 I.C.J. 12,72 (Mar. 31).

24. Medellin, 552 U.S. at 504.

25. Id. at 508-09.

26. Id. at 530 . 
adopted. ${ }^{27}$ Clearly, this gap in the domestic effectiveness of the international legal obligations of the United States could be filled by subnational implementation in the form of individual States passing legislation guaranteeing the rights accorded by the treaty. Individual States - California, Illinois, and Oregon - have enacted some form of State or local law to implement Article 36, but most have not. ${ }^{28}$

In many cases, subnational implementation of treaties is not necessary because of the correspondence of existing domestic law with the relevant treaty obligations. For example, in the case of the 1984 U.N. Convention Against Torture and Other Cruel, Inhuman or Degrading Treatment or Punishment, the Reagan administration determined that "implementing legislation was not necessary since existing federal and state law already provided grounds for prosecuting anyone accused of committing an act within the scope of the term 'torture' as defined by the Convention." 29 Since new, sweeping federal legislation was not needed, the goals of the treaty were given effect largely by State law - though the federal criminal code was amended to permit, in some situations, prosecution of acts of torture committed outside the United States. ${ }^{30}$

The contours of the distinction between self-executing and non-selfexecuting treaties were unclear from the outset, and they continue to trouble courts and scholars alike. In a recent formulation, the U.S. Supreme Court pronounced that "[a] non-self-executing treaty, by definition, is one that was ratified with the understanding that it is not to have domestic effect of its own force" and thus can only be enforced pursuant to duly-enacted legislation. ${ }^{31}$

Under this approach, unless so implemented, such a treaty does not create binding or enforceable federal law. Nonetheless, a constituent State may not constitutionally adopt legislation (or take other action) that would be contrary to an accepted treaty obligation of the United States, whether self-executing or not.

27. See Consular Notification Compliance Act of 2011, S. 1194, 112th Cong. (2011).

28. See generally David P. Stewart, The Emergent Human Right to Consular Notification, Access and Assistance, in THe CAMbridge HANDBOOK OF NEw Human Rights: RECOGNITION, NOVELTY, RHETORIC (Andreas von Arnauld et al. eds., forthcoming 2020).

29. Id. at $248-49$.

30. 18 U.S.C. $\ 2340$ A, added by Pub. L. No. 103-236, tit. V, \506(a), 108 Stat. 463 (1994); amended by Pub. L. No. 103-322, tit. VI, $\int 60020$, 108 Stat. 1979 (1994); Pub. L. No. 107-56, tit. VIII, \811(g), 115 Stat. 381 (2001).

31. Medellin, 552 U.S. at 527; see also id. at 505 n.2 ("The label 'self-executing' has on occasion been used to convey different meanings. What we mean by 'self-executing' is that the treaty has automatic domestic effect as federal law upon ratification. Conversely, a 'non-self-executing' treaty does not by itself give rise to domestically enforceable federal law. Whether such a treaty has domestic effect depends upon implementing legislation passed by Congress."); Missouri v. Holland, 252 U.S. 416 (1920) (finding some treaties require implementing legislation). 
For many years the issue of non-self-execution was a relatively technical one, largely left to the courts to decide on a case-by-case basis as the issue was presented in the specific context of litigation. ${ }^{32}$ With the post-World War II proliferation of multilateral treaties, however, and in particular the adoption of increasingly detailed human rights treaties, attention focused on the effect a ratified treaty would have on the related questions of (i) individual rights (i.e., when and in what circumstances could individuals rely on treaties to challenge the laws and actions of the States as well as the federal government for alleged violations of human rights), and (ii) federalism (i.e., to what extent could a treaty authorize the federal government to regulate subjects or spheres of activity traditionally within the purview of the States — such as family law). ${ }^{33}$

The underlying structural concerns (i.e., about questions of federalism, intrusion into State and local matters, and changing State and local law through the treaty power) have in some well-known instances actually prevented U.S. adherence to multilateral conventions. In particular, these issues have resulted in the Senate's refusal to give advice and consent to a number of human rights treaties, including the Convention on the Elimination of All Forms of Discrimination Against Women and the Convention on the Rights of Persons with Disabilities. Most tellingly, the executive branch has not even transmitted to the Senate the Convention on the Rights of the Child, which the United States signed in 1995 but today is the only country in the world not to have ratified, largely (but not exclusively) because of federalism issues. ${ }^{34}$

In part as a consequence of the resulting frustration on the part of human rights advocates, a number of initiatives have been undertaken in the United States to adopt the substance of some human rights treaties at the State, city and local levels. ${ }^{35}$ Even though States, cities and local

32. See Holland, 252 U.S. 416; Medellin, 552 U.S. 491; Republic of Marshall Islands v. United States, 865 F.3d 118 (9th Cir. 2017).

33. The latter question had, of course, been a source of controversy ever since the Supreme Court's decision in Holland, $i d$. In the period immediately following World War II and the creation of the UN, it had become especially contested in respect of federal efforts to force the segregationist states to change their laws. The conservative reaction took the form of the so-called "Bricker Amendment," which (in general terms) would have prevented use of the treaty power to change domestic law (inter alia by forbidding "self- executing" treaties). See generally DAVID SLOSS, THE DEATH OF TREATY SUPREMACY: AN INVISIBLE CONSTITUTIONAL CHANGE (2016); MARTIN

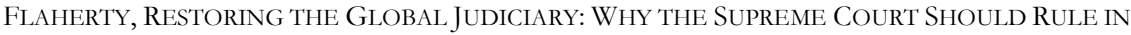
U.S. FOREIGN AFFAIRS (2019).

34. David P. Stewart, Ratification of Convention on the Rights of the Child, 5 GEO. J. FIGHTING POVERTY 161, 176 (1998).

35. David Kaye, State Execution of the International Covenant on Civil and Political Rights, 3 U.C. IRvine L. ReV. 95, 97-98 (2013); Closing THE GAP: THE FEDERAL Role IN RESPECTING \& ENSURing Human RightS AT THE STATE \& LOCAl LEVEL, COlum. L. SCH. Hum. RTS. INST. (2013) (discussing ways states, cities, and local governments can work to give effect to the purposes and principles of ICCPR). 
governments cannot directly "join" or become a "party" to any international treaty (whether or not ratified by the United States), they are not prohibited from adopting measures to give effect to some of the substantive requirements and protections of a treaty, as long as their implementation does not conflict with federal law. The extent to which an action might be considered "pre-empted" because of conflict with federal foreign relations authority or policy, presumably including obligations of international law, is a debated and unclear issue. ${ }^{36}$ On a more practical level, as Judith Resnik observes, "to look only at the national level is to miss a lot of the action." 37

By way of example, Chapel Hill, North Carolina, adopted the Universal Declaration of Human Rights (of course, not as a treaty or even a law, but as a standard for behavior) in 2009. In one fashion or another, Hawaii, Rhode Island and South Carolina, along with Austin, Chicago, New York, and Savannah are said to have endorsed the Convention on the Rights of the Child (at least its principles). ${ }^{38}$ In 1998, San Francisco famously adopted the Convention on the Elimination of all Forms of Discrimination Against Women ("CEDAW") as a local ordinance. Other U.S. cities have joined "Cities for CEDAW," which describes itself as a movement of city and local activists across the United States "aiming to incorporate the gender- equity principles and obligations of CEDAW into city governance and local city policies. Seven cities $^{39}$ have passed CEDAW ordinances. Twenty other cities have passed CEDAW resolutions affirming support for CEDAW principles. More than 30 other cities including Boston, Denver, New York, Philadelphia, Phoenix, Portland, Tacoma, and Washington, D.C. are considering either a

36. In Zschernig v. Miller, 389 U.S. 429, 440-41 (1968), the U.S. Supreme Court struck down an Oregon statute barring citizens of communist countries from inheriting property of in-state decedents, on the ground that - even in the absence of an applicable federal law or treaty - it constituted "an intrusion in the federal domain" with "a direct impact upon foreign relations [that] . . . may well adversely affect the power of the central government to deal with those problems." Id. at 441. The decision is often described as establishing a doctrine of "dormant foreign affairs preemption"; cf. Ingrid Wuerth, The Future of the Federal Common Law of Foreign Relations, 106 GEO. L.J. 1825 (2018). But see Am. Ins. Ass'n v. Garamendi, 533 U.S. 396, 421 (2003) (distinguishing between "field" and "conflict" pre-emption and noting that " $[\mathrm{t}]$ he exercise of the federal executive authority means that State law must give way where, as here, there is evidence of clear conflict between the policies adopted by the two").

37. Judith Resnik, The Internationalism of American Federalism: Missouri and Holland, 73 MO. L. REV. 1105, 1110 (2008).

38. See Bluhm Legal Clinic, N.W. U. Sch. Of L., ToOlkit For the Adoption of the CONVENTION ON THE RightS OF THE CHILD BY CiTY COUNCILS AND STATE LEGISLATURES 8 (2009).

39. The cities are San Francisco, California; Berkeley, California; Cincinnati, Ohio; Honolulu, Hawaii; Los Angeles, California; Miami-Dade County, Florida; and Pittsburgh, Pennsylvania. 
CEDAW ordinance or resolution. ${ }^{40}$ More recently, the Trump Administration's renunciation of the Paris Climate Agreement has apparently reinvigorated an effort at the subnational level to adopt measures giving effect to international undertakings on climate change. ${ }^{41}$

\section{THEORETICAL FRAMEWORK: UNDERSTANDING SUBNATIONAL IMPLEMENTATION}

Subnational implementation of international agreements results from one of the gaps between what we refer to as the normative and operating systems in international law. 42 What we see as a gap that impedes implementation of an international obligation may prove to be an important checkpoint to ensure adequate capacity to carry out the international obligation including the alignment of political interests. Described in more detail below, the normative system is directive in that it specifies the prescriptions and prohibitions for behavior among actors in the international system. The operating system is structural in that it provides the institutions and processes to regulate how law is created, implemented, and enforced.

\section{A. The Normative System}

"Normative" is used to describe the directive aspects of international law because this area of law creates norms out of particular values or policies. These norms are quasi-legislative in character because they direct specific changes in state and other actors' behaviors, such as limitations on child labor. ${ }^{43}$ In defining the normative system, the participants in the

40. See generally Cities for CEDAW: A CAMPAign to MAKe the Global Local (June Zeitlin et al. eds., 2017); David P. Stewart, Incorporating International Human Rights Law: Well Known Limitations and New Initiatives Taken at State, City and Local Levels, 38 HUM. RTS. L.J. 1(2018).

41. U.S. State Climate Action Plans, CTR. FOR ClimATE \& ENERGY SOluTiOns (Apr. 2019), https://www.c2es.org/document/climate-action-plans (suggesting many States have, or are developing, climate action plans); see also Audrey Comstock, U.S. Cities and States Want to Implement the Paris Climate Accord Goals. It's Not That Simple, WASH. POST, (June 13, 2017),

https://www.washingtonpost.com/news/monkey-cage/wp/2017/06/13/u-s-cities-and-stateswant-to-implement-the-paris-climate-accord-goals-its-not-that-simple/ (identifying the challenges States face in attempting to implement the Paris Climate Agreement on a subnational level); S.F., CAL. ENVTL. CODE ch. $1, \$ 100(E)$ (2008) (adopting the Precautionary Principle).

42. DIEHL \& KU, supra note 18 , at 2.

43. Our conception of a normative system is similar to what Hart defines as primary rules that impose duties on actors to perform or abstain from actions, but there is an important difference. See H. L. A. HART, THE CONCEPT OF LAW 151 (1961). Hart sees primary rules as the basic building blocks of a legal system, logically and naturally coming before the development of what we define as the operating system components. $I d$. at $91-92$. For Hart, a primitive legal system can be one with developed rules, but without substantial structures to interpret or enforce those rules. $I d$. at 89 . Our view of the normative system does not necessarily assign primacy to such rules vis-à-vis the operating 
international legal process engage in a political and legislative exercise that defines the substance and scope of the law. Nevertheless, the establishment of international legal norms still is less precise and structured than in domestic legal systems where formal deliberative bodies enact legislation.

In contrast to the general terms associated with topics of the operating system (see below, e.g., jurisdiction, actors or dispute resolution), the normative system is issue-specific, with many components within issue areas (e.g., status of women within the broader topic area of human rights). Many normative issues have long been on the agenda of international law, such as proscriptions on the use of military force or various rules concerning the law of the sea (e.g., seizure of commercial vessels during wartime). Others such as human rights and the environment have developed almost exclusively in the past seventy years.

\section{B. The Operating System}

The effectiveness of the normative system depends in large part on the operating system, the mechanisms and processes that are designed to ensure orderly processes and compliance with those norms, and change if problems signal a need for change. ${ }^{4}$ The operating system of international law sets out the consensus of its constituent actors (primarily states) on distribution of authority and responsibilities for governance within the system. Who, for example, are the authorized decision-makers in international law? Whose actions can bind not only the parties involved, but also others? How do we know that an authoritative decision has taken place? When does the resolution of a conflict or a dispute give rise to new law? These are the questions that the operating system answers. Note that the operating system may be associated with formal structures, but not all operating system elements are institutional. For example, the Vienna Convention on Treaties ${ }^{45}$ establishes no institutional mechanisms but does specify various operational rules about treaties and therefore the parameters of law making.

\section{Gaps in the Operating System}

The development of a new legal norm (or the extensive modification of an existing one) may produce changes in the international operating

system. The normative system may be somewhat autonomous from the operating system and may even lag behind in its development.

44. DIEHL \& KU, supra note 18, at 28-30; HART, supra note 43, at 209.

45. Vienna Convention on the Law of Treaties, May 23, 1969, 1155 U.N.T.S. 331. 
system. Yet the latter is far from guaranteed. First, the extant operating system may be able to accommodate the new norm with no changes required. For example, a new global trade agreement may comport well with existing World Trade Organization mechanisms, including its forum for dispute resolution. In this way, new norms do not upset the equilibrium between normative and operating systems.

In a second scenario, a new norm may arise that necessitates a change in the operating system in order to give the former full effect, but such a change does not occur because the operating system is incompatible, ineffective, or insufficient to give the new norm effect. For example, holding national leaders responsible for torture or other crimes (Convention on Torture) created new norms, but is incompatible with notions of sovereign immunity. The 1999 Spanish case against Chile's General Pinochet demonstrates this tension. ${ }^{46}$

Operating system change, although needed, may not occur, and as a result an imbalance is created between the operating and normative systems. Thus, certain norms will not have effect in the system; that is, they will not be implemented, observed, or enforced in an efficient manner. What is likely to happen as a result of this imbalance? The most obvious answer is nothing: the system remains out of equilibrium and new international legal norms have limited or no effect on behavior. Yet other possibilities exist. There are other processes by which the operatingnormative system imbalance can be redressed - all outside the formal international legal system. Subnational implementation is one of those processes. Let us briefly note some of the other possibilities. ${ }^{47}$

First, non-governmental organizations ("NGOs") can play a role as supplements to or substitutes for the international law operating system. The technical character of many issues now facing policymakers continues to make them, as they have been for decades, receptive to expert information. Thus, some NGOs are well positioned to assume roles in the implementation of norms, particularly in those areas in which specialized expertise is required.

Second, "soft law" mechanisms might be used for ensuring norm compliance. ${ }^{48}$ Despite some ambiguity, soft law mechanisms are broadly those that do not involve a formal legal obligation or legal processes, but nevertheless represent a shared understanding or consensus about procedure or behavior among the parties. In the context of the operating system, informal or soft mechanisms for resolving jurisdictional

46. R. v. Bow St. Metropolitan Stipendiary Magistrate, ex parte Pinochet Ugarte (No. 3) [1999] UKHL 17 [2000] 1 AC (HL) 147 (appeal taken from Eng.).

47. See DiEHL \& KU, supra note 22, at 108-25.

48. Gregory C. Schaffer \& Mark A. Pollack, Hard vs. Soft Law: Alternatives, Complements, \& Antagonists in International Governance, 94 MINN. L. REV. 706, 712-15, 719-21 (2010). 
disagreements (e.g., how to resolve disputes when overlapping jurisdiction is present) or disputes over substance (e.g., what diplomatic solutions are legitimized) represent soft law adaptations to inadequacies in "hard law" provisions. A growing body of empirical work shows that such informal mechanisms influence behavior. ${ }^{49}$

A third gap filling process is legal internalization. This occurs when an international norm is embedded in the national legal systems and domestic legal mechanisms pick up the slack left by inadequacies in international legal mechanisms. One form is legislative internalization, when domestic lobbying embeds international law norms into binding national legislation or even constitutional law that officials of a government must then obey as part of the domestic legal fabric. Local actors then attain standing to press claims and seek redress in domestic courts. The European Union represents a special case and one in which internalization has gradually become more routinized. 50 When national adoption of legislation does not occur or is not appropriate in a federal system, adoption might occur by governmental units at the subnational level.

Subnational implementation represents a special kind of approach to filling the gap left when the national legal operating system cannot give full effect to treaty obligations. In federal systems with independent component government entities (e.g., the United States or Canada) encompassing multiple layers of government, it might be impossible for international law to have immediate legal impact within a subnational unit without additional national or subnational action, that is without implementing legislation. In the U.S. system, this could be national legislation that results in federalizing areas that may otherwise be within State and local jurisdiction. Nevertheless, the power to federalize is limited. As noted in Bond v. United States:

49. See, e.g., Andrew T. Guzman \& Timothy L. Meyer, International Soft Law, 2 J. LEGAL ANALYSIS 171, 202 (2010) ("There is a broad consensus in the international law literature that the nonbinding rulings of international tribunals do, indeed, influence legal rules.”); Gregory Schaffer \& Tom Ginsburg, The Empirical Turn in International Legal Scholarship, 106 AM. J. INT’L L. 1, 39 (2012) (discussing the role of nonstate actors and "soft law" in the production of international environmental law); Chris Brummer, How International Financial Law Works (and How it Doesn't), 99 GEO. L.J. 257, 263 (2011) ("[E]ven where rules are not legally binding, they may still influence the behavior of regulators and market participants seeking to make credible commitments of efficiency, value, and strong corporate governance to investors."); Jacob E. Gersen \& Eric A. Posner, Soft Law: Lessons from Congressional Practice, 61 STAN. L. REV. 573 (2008) (discussing how soft law influences the behavior of other lawmaking bodies and of the public); Thomas A. Mensah, Soft Law: A Fresh Look at an Old Mechanism, 38 ENVTL. POL'Y \& L. 50, 51 (2008) (discussing how particular soft law principles and rules may be used to regulate or influence the operation of states and other actors in ways that contribute to the protection of the environment and sustainable development).

50. Anne-Marie Burley \& Walter Mattli, Europe Before the Court: A Political Theory of Legal Integration, 47 INT'L ORG. 41, 42 (1993). 
It has long been settled, for example, that we presume federal statutes do not abrogate state sovereign immunity . ... Closely related to these is the well- established principle that "it is incumbent upon the federal courts to be certain of Congress' intent before finding that federal law overrides" the "usual constitutional balance of federal and state powers." 51

As the level of government charged with carrying out the foreign relations of the United States, however, the federal government can in many cases preempt State and local law where inconsistent with U.S. international obligations. ${ }^{52}$

Indeed, some international legal obligations by their very character require changes in internal or national law. In federal systems, national legislation to implement treaty obligations might prove difficult given constitutional provisions and other devolution to lower level government entities. Soft law and the employment of NGOs are also not options in these situations to deal with the normative-operating gap. In these instances, the adoption of laws at the State or provincial level might be the way to ensure that treaty obligations at the national level are met and international norms influence behaviors in the manner intended domestically. We examine that process and its effectiveness in the United States in the following sections.

\section{The UNIFORM LAW COMMISSION AND SUBNATIONAL IMPLEMENTATION IN THE UNITED STATES}

51. Bond v. United States, 572 U.S. 844, 856-57 (2014).

52. For a contemporary example of a preemption conflict, see United States v. California, 921 F.3d. 865, 881-82 (9th Cir. 2019), an action initiated by the United States in response to the sanctuary movement claiming that three California laws were preempted due to conflicts with federal law. One limited the discretion of state and local officials to cooperate with federal immigration authorities (S.B. 54). Another required the state attorney general to inspect facilities where immigrants were being detained by federal agents while awaiting court dates or deportation (A.B. 103). A third prohibited public and private employers from cooperating with federal enforcement (unless such cooperation is mandated by a court order or a specific federal law), and required employers to notify employees of federal scrutiny (A.B. 450). The district court denied in most regards the United States' motion for a preliminary injunction. The court of appeals held that the district court had not abused its discretion in concluding that A.B. 450, including its employee-notice provisions, was not preempted; that S.B. 54's limitations on cooperation were consistent with the Tenth Amendment and the anticommandeering doctrine; but that one component of A.B. 103 discriminated against and burdened the federal government in violation of the intergovernmental immunity doctrine. As had the district court, the court of appeals distinguished Arizona v. United States, 567 U.S. 387 (2012), insofar as the State law regulated State law enforcement activities, and employer-employee relationships, rather than varying the techniques for regulating employers that Congress had already extensively (and exclusively) regulated. $I d$. 
Although subnational implementation might be required to give treaties their intended effect, there is no guarantee it will occur. There are a number of entities that provide the U.S. Department of State with useful advice on the issue of subnational treaty implementation. ${ }^{53} \mathrm{We}$ focus on one of these - the Uniform Law Commission ("ULC") 54 — and examine whether engaging the ULC and translating treaty obligations into uniform State legislation would improve the likelihood of States complying with international treaty obligations in the United States. Even if the mechanism of uniform State legislation is not required for a treaty to have its intended effect, the ULC plays a role in shaping implementation at the national level so the treaty is more congruent with existing State law.

Since its creation in 1892 the ULC has been a central player in the codification of State law in the United States. ${ }^{55}$ According to an FAQ posted on its official website, "the ULC is the nation's oldest State governmental association. A nonpartisan, volunteer organization, the ULC is the source of more than $300 \mathrm{draft}$ and proposed statutes that secure uniformity of state law when differing laws would undermine the interests of citizens throughout the United States." 56 There are commissioners from every State, the District of Columbia, Puerto Rico, and the U.S. Virgin Islands. A commissioner must be an attorney appointed by a governmental authority, most commonly the governor, and must serve as a volunteer who receives no salary or other form of compensation. ${ }^{57}$ The primary areas in which the organization has produced uniform acts are commercial law, family and domestic relations law, probate and trust law, real estate law, and the law governing alternate forms of dispute resolution, but there are uniform acts on a wide range of other topics.

Approval for the drafting of a uniform act must be based on a determination that uniformity among the States is desirable and practicable, and the purpose of a uniform act is to simplify "individuals' lives and facilitate business transactions by providing consistent rules and procedures from State to State. Every day, when a person conducts business, enters a contract, makes a purchase or sale, obtains or transfers

53. See, e.g., Office of the Legal Adviser, General Resources - Private International Law, U.S. STATE DEP'T, https://www.state.gov/general-resources-private-international-law/(last visited Jan. 1, 2020) (listing as resources the American Branch of the International Law Association, the American Law Institute, the Section on International Law of the American Bar Association, the American Society of International Law and the Uniform Law Commission).

54. The formal name of the Uniform Law Commission is the National Conference of Commissioners on Uniform State Laws. See UNIF. LAw. COMM’N CONST. art. 1, \ 1.1, 2009-2010 REF. BOOK 113 (2009). 1, 2020).

55. FAQs, UNIF. LAW COMM’N, https://www.uniformlaws.org/aboutulc/faq (last visited Jan.

56. Id.

57. Id. 
property, or takes care of a family matter, it is likely that a ULC law applies." 58

The ULC does not have lawmaking authority; rather, it drafts acts for the various jurisdictions to consider and enact. Because each jurisdiction's legislature has the ultimate enacting authority, even a uniform act may contain non-uniform provisions that reflect local interests. Although the ideal, sometimes achieved, is to make the laws among the jurisdictions uniform, as a practical matter the effect is most commonly to harmonize those laws.

ULC commissioners draft "specific acts; they discuss, consider, and amend drafts of other commissioners; they decide whether to recommend an act as a uniform or a model act; and they work toward enactment of ULC acts in their home jurisdictions." 59 These activities apply to broad sets of concerns, primarily domestic ones. The question for this paper is what role the ULC might play in the implementation of international law, particularly in subjects that have been principally domestic in character and within the domain of the States in the U.S. federal system. The issue is most pertinent in subjects in which the organization has drafted and gained implementation of a uniform act. Given the ULC's track record in harmonizing the laws of the more than fifty jurisdictions that comprise the U.S. federal system and given that implementation of a treaty at the federal level has a preemptive effect under the Supremacy Clause of the Constitution, ${ }^{60}$ it was inevitable that the ULC would play a role in implementing international treaty obligations.

The ULC has long recognized the preemptive power of international law implemented at the federal level. In his address at the 1956 annual meeting ULC President Barton H. Kuhns stated:

The problem of preserving through uniformity our state and local governments on the one hand, while seeking uniformity at an international level on the other, presents a sort of obstacle course into which one may tread only with extreme caution. The somewhat obvious method of unifying international law by treaty or convention might, at the same time, destroy the very sovereignty of the states which uniformity of state law is designed to protect. And yet, as the far corners of the world are gathered closer and closer together we will soon be reaching a point where the

59. Overview, UNIF. LAW COMM'N, https://www.uniformlaws.org/aboutulc/overview (last visited Nov. 24, 2019).

60. William H. Henning, The Uniform Law Commission and Cooperative Federalism: Implementing Private International Law Conventions through Uniform State Laws, 2 ELON L. REV. 39, 44 (2011). 
desirability of uniformity of the laws of different nations will become more and more apparent. ${ }^{61}$

One way to ameliorate the preemptive effect of federal law is to implement a treaty in part by drafting and enacting, in coordination with federal authorities, uniform State legislation. An early effort to do this occurred in the 1970s when the United States signed the Convention Providing the Uniform Act on the Form of a Will completed under the auspices of UNIDROIT.62 The Uniform Wills Recognition Act was developed by the ULC in coordination with the Department of State's Office of the Assistant Legal Adviser for Private International Law ("L/PIL") and was enacted in sixteen States, but the enactment process stalled for a complex set of reasons and the treaty has never been ratified Attempts to revive the project in the early 2000s were unsuccessful.63

More recently, ULC Commissioner and Delaware Judge Battle Robinson noted: "While the ULC's primary emphasis has been on unifying state law, in recent years, with the rapid increase of 'globalization,' the ULC has become more cognizant about the impact of international proposals on traditional areas of state law." 64

Commissioner Robinson described an important component of the ULC's efforts to keep abreast of international developments that might implicate State law as follows:

In 2003, in response to [increased globalization], the ULC created the Committee on International Legal Developments. The functions of this committee include monitoring activities of organizations in the international law field that may impact state law, making recommendations about establishing drafting committees to work on projects that involve international issues, and following the progress of ULC projects that are international in scope. ${ }^{65}$

61. NAT’L CONF. COMMisSiONERS ON UNIFORM STATE LAwS, HANDBOOK 42, 50 (1956).

62. The International Institute for the Unification of Private Law ("UNIDROIT") is an independent intergovernmental organization whose mission is to harmonize and to coordinate private and commercial law between states and among groups of states. For information about UNIDROIT, see History \& Overview, UNIDROIT, https://www.unidroit.org/aboutunidroit/overview (last visited Jan. 1, 2020).

63. The enacting States delayed effectiveness until the treaty was ratified and thus the act has never gone into effect anywhere.

64. B.R. Robinson, Integrating an International Convention into State Law: The UIFS A Experience, 43 FAM. L.Q. 61, 64 (2009).

65. Id. 
At about the same time the ULC adopted a formal policy regarding its approach to international matters. The 2006 Statement of Policy on International Activities explains:

With the movement toward globalization, the federal government increasingly participates in the promulgation of private international law conventions that, upon ratification, become preemptive federal law. This disrupts the law in areas such as commercial and family law that historically have been regulated at the state level and that have been the subject of numerous uniform and model laws promulgated by the Conference. The states have a profound interest in, to the extent practicable, having international conventions mesh with their existing laws, influencing the law's development in other countries so that it is compatible with American legal concepts, and harmonizing their own laws with the laws of other countries. This will facilitate transactions and movement across borders and will provide the citizens of the states a familiar and appropriate legal framework as they participate in the global community. For the same reasons it benefits our citizens and businesses to have uniform state laws, so too will they benefit by having their state laws work in harmony with the laws of other nations. ${ }^{66}$

The ULC's interest in international laws and agreements grows out of its mission to ensure that such laws and agreements are not "unduly disruptive of state interests." 67 As former ULC Executive Director William Henning has written:

$[\mathrm{T} \mathrm{t}$ is not surprising that the ULC and the State Department's Office of the Assistant Legal Adviser for Private International Law, known within State as L/PIL, have developed a close working relationship. Each has a distinct sphere of interest and there is a tension between those spheres, yet there is sufficient overlap that a significant level of cooperation is in the interests of both. ${ }^{68}$

66. Policy Position on International Activities, UNIF. ACTIVITIES ENEWSLETTER (UNIF. LAW COMM'N), MAY 2006, Uniform Law Commission, Executive Committee Handbook, Item eIII.I.4. The handbook. which contains all ULC policies, is continuously updated and a copy of the version in effect as of January 1, 2020 is on file with William Henning. See Henning, supra note 60, at 41.

67. Henning, supra note 60 , at 43 .

68. Id. at 43-44. 
This cooperation can be further seen in the presence of senior members of L/PIL serving as advisory members of the ULC. L/PIL has also regularly reached out to the ULC, among other stakeholders and interested parties, for help in formulating negotiating positions, to staff delegations, and in identifying relevant expertise. ${ }^{69}$

Although the U.S. Constitution prohibits States from becoming parties to international conventions, there is nothing in the Constitution that prevents States from cooperating with the federal government, even though they are not required to, by implementing them at the State level through appropriate State legislation unless the Constitution vests the matter with the federal government. ${ }^{70}$ Indeed, we will see below the advantages of developing an implementation plan during international negotiations for obligations that affect State laws. When there are ULC products and drafting experience available to facilitate the implementation process at the State level, this should enhance the ability of the United States. to ratify such agreements. ${ }^{71}$

For example, a treaty could be negotiated by federal authorities with ULC experts serving on the negotiating delegations or otherwise assisting in the negotiating process, followed by States enacting uniform laws promulgated by the ULC in cooperation with federal authorities. After the ground had been prepared in this manner the treaty would be formally adopted with Senate advice and consent and executive ratification. This occurred with regard to the Hague Convention on the International Recovery of Child Support and Other Forms of Family Maintenance (Child Support Convention), aspects of which are discussed in the ensuing sections. ${ }^{72}$ The ULC worked closely with L/PIL and the Office of Child Support Enforcement ("OCSE") in the Department of Health and Human Services to develop the convention; ULC-related experts served on the negotiating delegation; and the Uniform Interstate Family Support Act ("UIFSA"), already in effect in every ULC jurisdiction, was amended to include the substantive provisions of the convention, thereby empowering the State agencies that collect child support domestically to do so internationally. The Senate gave its advice and consent and federal legislation was adopted conditioning federal funding for child support

69. See Curtis R. Reitz, Globalization, International Legal Developments, and Uniform State Laws, 51 LOY. L. REV. 301, 308 (2005).

70. Henning, supra note 60 , at $44-45$.

71. Reitz, supra note 69, at 327.

72. Mary Helen Carlson, United States Perspective on the New Hague Convention on the International Recovery of Child Support and Other Forms of Family Maintenance, 43 FAM. L.Q. 21, 26-31 (2009) (containing an excellent discussion of the project). 
collection in a State on enactment of amended UIFSA in that State. ${ }^{73}$ Amended UIFSA was enacted in every ULC jurisdiction and the instrument of ratification was deposited with the Hague Conference on Private International Law, thereby making the United States a party to the convention effective January 1, 2017.74

The child-support project was a spectacular success, but in many instances not all of the events necessary for success will occur and those that do can occur in various sequences. The ULC might be involved in some or all of the stages as we note below.

\section{A. The ULC Development and Enactment Process}

An understanding of the ULC's role in international matters requires an understanding of the organization's ordinary processes applicable to the development of domestic State law. The ULC places no restrictions on where proposals for new projects originate. Proposers are generally from State bar associations, State governments, private groups, ULC commissioners, joint and permanent editorial boards, ${ }^{75}$ and individuals. Proposals are reviewed by the Committee on Scope and Program, which makes a recommendation to the Executive Committee as to action. The possible outcomes of the Scope Committee's review are:

- Dismiss the proposal as not viable;

- Request that the proposer develop the idea further;

73. 42 U.S.C.A. \666(f) ("In order to satisfy section 654(20)(A) of this title, each State must have in effect the Uniform Interstate Family Support Act, as approved by the American Bar Association on February 9, 1993, including any amendments officially adopted as of September 30, 2008 by the National Conference of Commissioners on Uniform State Laws.").

74. For a list of parties to the Convention of 23 November 2007 on the International Recovery of Child Support and Other Forms of Family Maintenance, see Status Table, HAGUE CONFERENCE ON PRIVATE INT'L LAW, https://www.hcch.net/en/instruments/conventions/statustable/?cid=131 (last visited Jan. 1, 2020).

75. Editorial boards are partnerships with other organizations (most commonly a section of the American Bar Association but often another professional organization), have their own budgets, are typically staffed by a scholar with expertise in the area, and often have advisors or liaison members from organizations that are not formally part of the partnership. The editorial boards are: The Permanent Editorial Board for the Uniform Commercial Code (with the American Law Institute); Joint Editorial Board for Uniform Real Property Acts (with the American Bar Association's Real Property, Trust, and Estate Section, American College of Real Estate Lawyers, American College of Mortgage Attorneys); Joint Editorial Board for Uniform Family Laws (with American Academy of Matrimonial Lawyers, Association of Family and Conciliation Courts); Joint Editorial Board for International Law (with ABA International Law Section); Joint Editorial Board for Uniform Unincorporated Entity Acts (with the American Bar Association's Business Law Section); and the Joint Editorial Board for Uniform Trust and Estate Acts (with the American Bar Association's Real Property, Trust, and Estate Section, American College of Trust and Estate Counsel). 
- If the proposal did not originate with a joint or permanent editorial board, forward it to the appropriate editorial board for further analysis and recommendation;

- Recommend the formation of a study committee; and

- Recommend the formation of a drafting committee

The normal process was followed with regard to the child- support project discussed above. The project began when Mary Helen Carlson, the L/PIL attorney-adviser who headed the U.S. delegation that negotiated the Child Support Convention, appeared before the Scope and Program Committee at the ULC's July 2006 annual meeting to explore the formation of a drafting committee to integrate the convention into UIFSA. ${ }^{76}$ Scope and Program recommended the project to the Executive Committee, which concluded that it should be undertaken. A drafting committee was formed in March 2007 that was chaired by Commissioner Robinson ${ }^{77}$ and included individuals who were participating in or serving as observers at the international negotiations in the Hague. ${ }^{78}$

Understanding the role the ULC plays in international matters requires an understanding of the painstaking process by which any uniform act is prepared. ${ }^{79}$ A project typically begins with a study committee, consisting of a chair, ULC members, often a reporter drawn from academia, and an advisory member from the ABA (all ULC study and drafting committees have ABA advisory members). The study must be open to non-ULC participants and the organization goes to great lengths to identify entities and individuals with an interest in the subject area. Depending on the topic, certain of these "stakeholders" will be obvious and will have been contacted by the ULC staff before the first meeting of the committee. Indeed, one of the first steps in many study projects is a "stakeholders meeting" at which those stakeholders that have been identified are asked to give their views on whether a proposed project makes sense, whether the ULC would be the right organization to draft an act, and whether the stakeholders are willing to participate in the drafting process. Among the study committee's ongoing tasks is the identification and outreach to other stakeholders, including academic experts who might be willing to participate. The formal ULC term for all

76. See Robinson, supra note 64 , at 65.

77. The reporter for the project was Professor John J. Sampson of the University of Texas School of Law, a noted international expert in the field of family law.

78. Further coordination with the treaty drafting project was seen in the presence of William Duncan, Deputy Secretary-General of the Hague Conference, who attended the initial session of the UIFSA drafting committee. See Robinson, supra note 64, at 67.

79. Much of the description of the proceedings was provided by one of the co-authors, who is a Life Member of the ULC (meaning he has served as a commissioner for at least 20 years and been elected to life-member status) and served as its Executive Director from 2001 to 2007. 
stakeholders is "observers" but the label is a misnomer — stakeholders are participants and are encouraged to speak at all committee meetings. No study or drafting committee is permitted to meet without its stakeholders being present. Most study committee meetings are held by phone or, increasingly, by computer platform.

If the study committee recommends a drafting project, it must be approved by the Committee on Scope and Program and by the Executive Committee. The composition of the drafting committee will be similar to the composition of the study committee (ULC chair, reporter - there is always a reporter on drafting projects), ULC members, ABA advisory members, and observers). Drafting committees typically meet in person twice a year - once in the fall and once in the spring — on a Friday and Saturday. The most common arrangement is for several drafting committees to meet in the same location, and the leadership of the ULC participates in the meetings (they rotate from meeting to meeting but all will be in attendance when critical issues are discussed). ${ }^{80}$ Each draft is submitted to the Committee on Style, which tightly edits it according to the ULC's style standards. It is important for each of the ULC's acts to speak in the same voice and the recommendations of the Committee on Style are mandatory unless the drafting committee presents a compelling substantive reason not to implement them.

The ULC holds an annual meeting each summer (usually in July) and at the meeting each drafting committee sits on a dais and reads its act to the assembled group of commissioners who have access to microphones in order to interact with the committee. Many issues are hotly debated. If the drafting committee will not accept a suggestion for changing the draft from the floor, the commissioner making the recommendation may make a motion and, if it is approved, the committee must comply. The floor has the ultimate say on all acts.

Each act must be read at two or more annual meetings before it can be approved as a final act of the ULC (on rare occasions, the two-reading rule has been waived). When a new uniform act is approved by a formal vote of the States, it is typically forwarded to the ABA with a request for a resolution of support from the House of Delegates, which is usually forthcoming. ABA approval is desirable but not required for the act to be presented to States for enactment. Each uniform act is accompanied by a set of official comments, which are produced by the chair and reporter. Although the comments are widely circulated for input before being

80. The leadership consists of the President, the Chair of the Executive Committee (the presumptive next president), and the Executive Director. The President is a volunteer commissioner elected by a majority vote of the commissioners and serves a two-year term. The Chair of the Executive Committee is also a volunteer commissioner and is appointed by the President. The Executive Director is a professional employee of the ULC. 
finalized, they are not approved by the floor. If an act is approved at an annual meeting in July, the comments are typically complete by October so that the act can be available to states in the legislative session beginning the next January.

The enactment process is overseen by the Legislative Committee, which consists of a chair and a group of commissioners with experience in the legislative process. Members of the committee often have experience as legislators or lobbyists. There is a liaison member from each State's delegation of commissioners. The Legislative Committee is supported by a staff consisting of a chief counsel, a program/communications director, and several attorneys. The Legislative Committee develops a plan for the enactment of each uniform act.

Gaining enactment is difficult even though commissioners from each State are obligated "to procure consideration by the legislature of the State, unless the commissioners consider the act inappropriate for enactment in their state." 81 A legislator in each State must be identified who will sponsor the act - ideally there will be a sponsor in each house of the legislature. It is surprisingly difficult to find sponsors for "good government" types of acts. A legislator may only have an opportunity to introduce one or two bills during a session and will want to be sure they are on topics that will be perceived as important by constituents. Because the ULC has a delegation from each State that has been appointed by the political authorities within the State, good connections to legislators exist and this facilitates the introduction of acts. ULC permanent staff assigned to the enactment process get to know some legislators in various States who can be counted on to be supportive of ULC acts.

Despite the sustained and regular engagement with stakeholders, opposition can still emerge. If the opposition is organized it can prevent enactment. The solution is sometimes to negotiate with the opposition and modify the act to meet the concerns but only in a manner that is consistent with sound public policy. This slows the process down as any substantive modifications have to be approved by all commissioners (there are streamlined procedures for obtaining approval in limited circumstances, but they still take time). Often, an act will first be referred to a state bar association, which will form a committee to review it and make recommendations to the legislature. This can be extremely helpful but is also time consuming.

81. Unif. Law Comm’n, Executive Committee Handbook, Item III.C, Policy ESTABLISHING CRITERIA AND PROCEDURES FOR DESIGNATION AND CONSIDERATION OF ACTS If 5 (2018), reprinted in UNIF. LAW COMM'N, 2018-2019 REFERENCE BOOK 185 (2018). The Reference Book is not distributed to libraries or posted online but is an invaluable resource, with copies sent to all commissioners and to anyone else upon request. 
The most successful enactment strategy involves a coordinated campaign by the ULC and the stakeholders that have participated in the drafting of the act and have become convinced of the importance of enactment. The ULC obtains support letters from stakeholders and, whenever possible, the stakeholders are asked to assist with a lobbying effort. There are times when a uniform act is highly successful occasionally gaining enactment in all States, sometimes in forty or more States. The ULC considers an act to have been successful if it is enacted in fifteen to twenty States. Some of the acts gain only a handful of enactments and some are not enacted anywhere.

\section{A. ULC Participation in Treaty Negotiation and Domestic Implementation}

The above discussion should not be understood to suggest that the ULC only becomes involved when treaty negotiations are underway or to suggest that implementation must occur through uniform legislation. The ULC has a robust relationship with L/PIL and often becomes involved at a much earlier stage and in a variety of ways. An understanding of these points requires an understanding of the ULC's internal structure as applied to international issues. ${ }^{82}$

An important element of the ULC's international efforts is the Joint Editorial Board for International Law ("JEB/IL"), a partnership between the ULC and the ABA Section on International Law that was created in 2007 and charged with (1) recommending as appropriate the adoption of uniform State laws on international and transnational subjects; (2) advising and assisting the federal government in international negotiations; (3) promoting education about the rule of law and the harmonization of law at the international level; and (4) furthering the goals of the ULC and the ABA section. 83

Representatives of L/PIL regularly attend meetings of the JEB/IL to brief the members on existing and prospective projects and to assist in fulfilling the board's responsibilities. Recently, Peter Lown, former President of the Uniform Law Conference of Canada, ${ }^{84}$ joined the

82. For an excellent and thorough discussion of the history of the ULC's international activities, see ROBERT A. STEIN, FORMING A MORE PERFECT UNION: A History OF THE UNIFORM LAW COMMISSION, ch. 10 (2013). 3, 2007).

83. Memorandum of Understanding from the Joint Editorial Board for International Law (Jan.

84. The ULC has a longstanding and very close relationship with the Uniform Law Conference of Canada (ULCC). The President of the ULCC regularly attends and makes a presentation the annual meeting of the ULC and the ULC President does likewise with regard to the ULCC's annual meeting. The ULC also has a close relationship with the Mexican Center for Uniform Law. The ULC and the ULCC have undertaken multiple joint drafting projects in an attempt to harmonize the laws of the two countries and the Mexican Center has often participated. A standing charge to the ULC's 
JEB/IL as Director of Research, greatly strengthening its capacity to make informed recommendations. The ULC's International Legal Developments Committee is charged with serving as liaison to the ULC's Canadian and Mexican counterparts and to the State Department. The committee reviews proposed international projects, often relying on reports from the JEB/IL, and makes recommendations to the Executive Committee.

The ULC often becomes involved when an international project undertaken by the State Department is in the negotiation stage and sometimes earlier. For example, L/PIL consulted with the ULC on the advisability of undertaking the project that ultimately led to the 2019 U.N. Convention on International Settlement Agreements Resulting from Mediation $^{85}$ (Singapore Mediation Convention), which deals with the recognition and enforcement of international mediated settlement agreements. The ULC president appointed a working group to study the matter and to advise L/PIL on the advisability of the project. The working group continued to advise L/PIL after the project commenced at the U.N. Commission on International Trade Law ("UNCITRAL"), and former ULC President Harriet Lansing, who chaired the working group, served as a government expert on the U.S. delegation that negotiated the convention.

By becoming involved in international negotiations on a subject for which the ULC had developed a uniform act, commissioners and former reporters involved with the drafting of that act or who are otherwise experts in the field can contribute their knowledge and experience dealing with legislative and policy issues required to harmonize laws in the State jurisdictions on that particular subject. For example, Commissioner Lansing was able to bring expertise gained through the process of developing the ULC's Uniform Mediation Act ${ }^{86}$ to the negotiations that led to the promulgation of the Singapore Mediation Convention.

As with Commissioner Lansing, representatives with ULC experience are often included as government experts on U.S. delegations to negotiations of particular conventions that would affect State laws, such as the U.N. Convention on the Assignment of Receivables, which is

Scope and Program and Executive Committees when considering international projects is to ask whether the project might be appropriate for collaboration with its Canadian and Mexican counterparts.

85. See U.N. Convention on International Settlement Agreements Resulting from Mediation, G.A. Res. 73/199 (Dec. 20, 2018).

86. The Uniform Mediation Act (UMA) was approved in 2001 and the next year UNCITRAL promulgated the Model Law on International Commercial Conciliation. Responding to this development, the ULC amended UMA Section 11 in 2003 to encourage parties from different countries to mediate commercial disputes in accordance with the UN Model Law. See NAT'L CONF. COMMISSIONERS ON UNIFORM ST. LAWS, UNIFORM MEDIATION ACT \11, prefatory note (2003). 
discussed further below. As noted above, this occurred in the drafting of the Child Support Convention, where both Commissioner Robinson and Professor Sampson, the chair and reporter of the drafting committee that amended UIFSA, served on the negotiating delegation.

Another example of this synergy may be found in the drafting of UNIDROIT's Convention on International Interests in Mobile Equipment (Capetown Convention), especially its Protocol on Matters Specific to Aircraft Equipment, ${ }^{87}$ which drew on the ULC's experience revising Article 9 of the Uniform Commercial Code on secured transactions. Professor Charles Mooney of the University of Pennsylvania Law School, who was co-reporter for the revision of Article 9 and Commissioner Edwin E. Smith, who was a member of the drafting committee for the revision, served on the U.S. delegation that negotiated the convention. 88

The Child Support Convention, discussed above, is the most successful example of the partnership between the ULC and the State Department and the only example to date of an international private law convention being ratified by the United States but implemented in large measure by a uniform law enacted in every State. Much of its success is owed to the exceptional process developed jointly by the ULC and its federal partners, L/PIL and OCSE. All delegation members met throughout the negotiating period to coordinate the U.S. position. The U.S. delegation also held meetings throughout the negotiating period "with relevant private sector stakeholders and government entities to obtain the requisite expertise and guidance on both the general direction the United States should take in this negotiation and the specific positions the U.S. delegation should pursue." 89

The Secretary of State's Advisory Committee on Private International Law organized a Study Group on International Child Support that held regular meetings open to the public and announced through the Federal Register. Members of the U.S. delegation made presentations at training sessions for State and local child support officials and at meetings of the ULC, National Child Support Enforcement Association, and the ABA. As Carlson noted:

87. The Aircraft Protocol to the Convention, commonly known as the Capetown Convention, has been ratified by the United States as a self-executing treaty. See Protocol to the Convention on International Interests in Mobile Equipment on Matters Specific to Aircraft Equipment - Status, UNIDROIT https://www.unidroit.org/status-2001capetown-aircraft (last visited Jan. 1, 2020). The other protocols to the convention (rail and space) have not been, and are unlikely to be, ratified. A fourth protocol on mining, agricultural, and construction equipment is currently being negotiated and Professor Mooney is participating as a U.S. delegate.

88. Reitz, supra note 69 , at 311.

89. Carlson, supra note 72 , at 25 . 
The goal of this inclusive process was to include every interest group in the process of developing the U.S. position on the legal and policy issues that arose in this negotiation. It was of paramount importance to the U.S. delegation that no one was left out and that every interested party had an opportunity to be heard. The U.S. delegation wanted to produce a Convention that met the needs of America's families, children, and the child support community, and one that that community would broadly and strongly support during the ratification process. ${ }^{90}$

In a similar manner, former ULC Executive Director William Henning and Professor Neil Cohen of Brooklyn Law School ${ }^{91}$ are longtime members of the U.S. delegation to Working Group VI of UNCITRAL that produced the U.N. Model Law on Secured Transactions in 2016, the Enactment Guide to the U.N. Model Law on Secured Transactions in 2017, and the Practice Guide to the Model Law on Secured Transactions in 2019. Secured transactions reform in developing countries is among the highest priorities of both UNCITRAL and the World Bank and the model law is an important instrument in furthering the reform efforts.

The U.S. delegation to Working Group IV of UNCITRAL is part of a broader team that attends the meetings, typically a week in Vienna in late fall and a week in New York City in mid-spring, under the flags of various NGOs. Organizations represented in these negotiations include the American Bar Association, the Commercial Finance Association (which consists of members engaged in asset-based securitization transactions), the International Insolvency Institute, and the National Law Center. The team collaborates extensively, both in preparing for the meetings and at the meetings.

The primary job of a government expert is to provide subject matter expertise. A great deal of effort goes into preparing for the UNCITRAL meetings. The U.N. Secretariat produces a new draft for each meeting, based on decisions made at the previous meeting. Those decisions are set

90. Id.

91. Jeffrey D. Forchelli Professor of Law. Professor Cohen is not a commissioner but his ties to the ULC run deep. He is a member of and Research Director for the Permanent Editorial Board for the Uniform Commercial Code, a frequent member of drafting committees revising articles of the UCC (including serving as co-reporter for the 2004 revision of Article 1), and he has served as an American Law Institute representative to ULC drafting projects that implicate the UCC in some manner, such as the 2015 revisions to the Model Tribal Secured Transactions Act and the Revised Uniform Landlord and Tenant Act. Professor Cohen's service on the U.S. delegation dates back to the 1990 s when he participated in the development of the U.N. Convention on the Assignment of Receivables. 
out in a report that is produced during the meeting at which they are made and approved by the delegates. As delegates prepare for a new meeting, they review the report from the previous meeting and the new draft that was prepared in light of the report. Suggestions for changes are made to the draft. Delegates then hold a series of telephone conferences, often lasting for hours, with the full U.S. team (including NGOs) going through the draft line by line. All involved make suggestions for drafting clarity that are provided privately to the Secretariat rather than publicly presenting them on the floor. Delegates, including the non-government experts, also make suggestions for substantive changes that the delegation hopes to achieve during the next meeting. Sometimes the changes merit the preparation of a working paper to be distributed to all delegations ahead of the meeting. This approach allows for input from other delegations and the opportunity to lobby them to join an effort. ULC members might speak on behalf of the U.S. government on certain issues in their expertise, and they have the opportunity to learn the positions of other State representatives and thereby potentially influence future drafting by the ULC. 92

The week-long UNCITRAL meetings are divided into sessions - a morning and afternoon session on Monday through Thursday and a morning session on Friday. The afternoon session on Friday is reserved for the reading and approval of the report of the proceedings. There is typically a special Experts Meeting on Saturday to which some experts from delegations and NGOs are invited and all government officials are excluded. U.S. experts have attended. The purpose of the meeting is to help the Secretariat work through the most complicated issues that it will have to deal with in the next draft. At the Experts Meeting, those in attendance are expected to take off their hats as state delegates and provide the best technical advice possible. The Experts Meeting is never referred to on the floor of UNCITRAL - because not every delegate is invited to attend and official recognition might ruffle some feathers. The Secretariat takes advantage of the experts in developing the next draft, often sending out advance drafts and asking for input. The drafts are not shared with the government delegates. As Henning noted, "we are acting on these occasions, with the permission of the United States, as U.N. experts." 93 The involvement of recognized experts helps to build confidence among domestic constituencies that U.S. interests and practices are duly considered in the negotiating process. This process of

92. E-mail from William Henning, Life Member, Uniform Law Commission, to Charlotte Ku, Professor, Texas A\&M University School of Law (Sept. 9, 2018, 10:00 EDT) (on file with authors).

93. Id. 
engagement with experts, stakeholders, and interested parties, including the public, occurs as a matter of general practice through the Secretary of State's Advisory Committee on Private International Law that meets on a periodic basis. ${ }^{94}$

The participation of ULC experts during the negotiations of international law conventions and other international instruments improves the quality of the conventions and instruments and makes them more congruent with existing State law. When it comes to the domestic implementation of a convention in an area that is the subject of existing uniform State legislation, the ULC's preferred approach is a collaborative effort with the State Department and other affected federal agencies resulting in ratification at the federal level but implementation in whole or in part at the State level through the development and enactment of a uniform law. This approach was used successfully with the Child Support Convention but it failed with the Wills Convention. Uniform State legislation, however, is only one of the ways in which the ULC can affect domestic implementation. Another, and very important method, is described below in connection with the discussion of the U.N. Convention on the Assignment of Receivables.

\section{A. The United States and Analogues in Other Federal Systems}

Although the analysis is confined to the United States, issues of subnational implementation are faced in other federal government systems. Specifically, Australia, Canada, India, Brazil, and Mexico, to name some of the most prominent examples, have multiple levels of government below the national level. For example, Canada is divided into provinces, each with its own government and sets of responsibilities. Like the United States, Canada has the Uniform Law Commission of Canada (ULCC), Australia has a federally funded office, and Mexico has a Uniform Law Committee.

The specifics of subnational treaty implementation in those countries are unique to the constitutional and other legal parameters found there. Nevertheless, a comparison with the United States on several dimensions reveals a particularly high bar for achieving subnational implementation in the United States. At the outset, the U.S. Constitution requires that no treaty be made without the advice and consent of the Senate, and that the treaty may be ratified only with concurrence of two thirds of the Senate. ${ }^{95}$ That level of support is difficult to achieve under the best of

94. See Office of the Legal Adviser, Advisory Committee on Private International Law, U.S. DEP'T OF STATE, https://www.state.gov/advisory-committee-on-private-international-law/ (last visited Jan. 1, 2020).

95. U.S. CONST. art. II, \ 2. 
circumstances, but the polarization of American political parties in the last decade, combined with frequent divided partisan rule between the executive and Congress, might make this hurdle particularly challenging.

In contrast, the federal authorities of Canada and Australia have evolved practices of coordination among and consultation with their subnational units prior to undertaking treaty negotiations. In Canada, treaty-making is "a prerogative power that has remained with the sovereign, that is, the "crown in right of Canada." 96 Since 1947, this power has been delegated to the Governor General of Canada. The Governor General exercises this power on the advice of ministers principally the Minister of Foreign Affairs and International Trade in the case of treaty making per Section 10 of the Department of Foreign Affairs and International Trade Act. ${ }^{97}$ Treaties do not automatically become the law of the land in Canada. If a change in existing law is required, the federal or provincial legislatures will need to act "depending on which level of government has general legislative competence in the relevant field as set out in the constitution." 98 This was underscored in a 1937 Privy Council decision generally known as the "Labour Conventions case." 99

The Canadian federal government begins a consultation process with the provinces to identify interested parties and relevant issues when it considers entering into a treaty of importance. The level of coordination and authorization will depend on the nature of the treaty. For matters of national significance that cut across several departments and require change to existing law, a policy decision of the Cabinet is required. For areas such as mutual legal assistance treaties that fit into existing statutes, and do not raise policy issues, the level of authorization is lower. Nevertheless, the making of all treaties in Canada requires "formal legal authority for their execution." 100 This consultation is overseen by the Privy Council Office which has been described as essentially the Prime Minister's department. ${ }^{101}$ Government departments and agencies may also be involved in these initial consultations.

Once this exploratory phase is completed, the Department of Foreign Affairs presents a "Memorandum to Cabinet" to secure political endorsement to embark on negotiations. The memorandum "analyzes the issues and risks related to the proposed agreement, includes the results of any environmental assessments and suggests guidelines for the

96. Maurice Copithorne, National Treaty Law and Practice: Canada, 33 STUD. TRANSNAT'L LEGAL POL'Y 1 (2003).

97. Dep't of Foreign Affairs and Int'l Trade Act, R.S.C. 1985, c E-22 (2013).

98. Copithorne, supra note 96 , at 1.

99. Id. at 4.

100. Id. at 3 .

101. France Morrissette, Provincial Involvement in International Treaty Making: The European Union as a Possible Model, 37 QueEN’s L.J. 577, 580 (2012). 
negotiations. With this information, the Cabinet then finalizes and endorses the negotiation mandate."102 Once negotiations are completed, the federal government can commit Canada to an international agreement. The power to enter into treaties, however, "did not automatically give [the federal government] a right to implement a treaty if its subject matter fell within provincial jurisdiction." 103

Since the mid-1970s, ad hoc federal-provincial committees of deputy ministers have been established to serve as a consultation mechanism for the negotiation and implementation of treaties like free trade agreements. The practice became more permanent in 1986 on conclusion of an agreement between federal and provincial authorities to create a mechanism for regular consultation among first ministers in order to monitor ongoing negotiations. Negotiating positions were also developed in consultation with the premiers and provincial trade ministers in the case of trade negotiations. 104 A similar mechanism for ongoing federal and provincial consultation used for officials responsible for human rights. When no specific legislation is enacted, the federal government may accept assurances from the provinces "deemed sufficient for the federal Government to accede to the treaties."105

The Canadian federal government, in principle, will not ratify a treaty on a subject that falls within provincial jurisdiction until relevant provincial implementing legislation is enacted. ${ }^{106}$ In practice, however, the federal Government has three options if a province chooses not to participate in a treaty regime.

First, the federal Government can withhold accession or ratification until all provinces enact required legislation. Second, some treaties may contain a "federal State" clause that allows the federal State to participate on a partial basis, i.e. participation to "the extent to which its political subunits have implemented the provisions of a treaty."107 The final option is for the federal State to enter a reservation to the treaty indicating which

102. Id. at 581; see also International Trade Agreements and Local Government: A Guide for Canadian Municipalities, GLOBAL AFFAIRS CANADA, https://www.international.gc.ca/trade-agreementsaccords-commerciaux/ressources/f $\mathrm{cm} /$ complete-guide-complet.aspx?lang=eng (last visited Jan. 1, 2020). For information on the Memorandum to Cabinet process, see PRIVY COUNCIL OfFICE, A DRAFTER's GUIDE TO CABINET DOCUMENTS (2013), https://www.canada.ca/en/privycouncil/services/publications/memoranda-cabinet/drafters-guide-documents.html.

103. Morrissette, supra note 101, at 584.

104. Id. at 585.

105. Copithorne, supra note 96 , at 6.

106. Morrissette, supra note 101, at 595.

107. Copithorne, supra note 96, at 6. For example, Article 93 of the 1980 United Nations Convention on the International Sale of Goods permits such a practice, but it has never been used by the United States. 
provinces decline to be bound where the treaty in question permits such a reservation although such provisions have become increasingly rare. ${ }^{108}$

The province of Alberta, for example, initially declined to be bound by the U.N. Convention on the Rights of the Child. (It has changed its position and is now bound.) ${ }^{109}$ Canada's system of consultation now also includes engaging with the public through parliamentary committees or other forms of consultation like the standing external consultative committee of the Department of Justice that advises principally on private international law treaties. The government is not bound to accept any of the advice provided and "the extent to which their recommendations are taken into account varies significantly." 110

In Australia, Section 61 of the Constitution gives the federal executive the authority to enter into treaties.111 Parliament, however, retains its legislative authority to incorporate treaty provisions into the domestic law of Australia. ${ }^{112}$ In the 1980s, Australian parliamentarians initiated a review of Australia's treaty-making process and specifically the role of the legislature in that process. The move was thought in some quarters to be unnecessary because Australia had generally followed UK practice where no treaties are self-executing. All treaties require domestic implementation in order to have legal effect. Nevertheless, by 1996, a series of treatymaking reforms were enacted to institutionalize notice and consultation with parliament and the states as follows:

- The tabling in Parliament of all treaty actions proposed by the government for at least fifteen joint sitting days before binding treaty action is taken;

- The preparation of a National Interest Analysis ("NIA") for each treaty, outlining information regarding the obligations contained in the treaty and the benefits for Australia of entering into the treaty - the NIA must be tabled in Parliament and published on the internet;

- The establishment of the parliamentary Joint Standing Committee on Treaties ("JSCOT"), comprising sixteen members from government, opposition and minority parties, to inquire into and make

108. See David Golove, Treaty-Making and the Nation: The Historical Foundations of the Nationalist Conception of the Treaty Power, 98 MiCH. L. REV. 1075, 1273 (2000) (citing to RESTATEMENT (THIRD) OF THE FOREIGN RELATIONS LAW OF THE UNITED STATES $\ 302$ reporter's note 4 (AM. LAW INST. 1987)).

109. Copithorne, supra note 96 , at 7.

110. Id.

111. Australian Constitution s 61.

112. DONALD R. ROTHWELL \& EMILY CRAWFORD, INTERNATIONAL LAW IN AUSTRALIA 51 (3d ed. 2017). 
recommendations in relation to Australia's entry into treaties

- The establishment of the Treaties Council, comprising the Prime Minister, Premiers and Chief Ministers and an enhanced role for the Commonwealth/state and territory Standing Committee on Treaties ("SCOT") to improve the quality of state and territory participation in the treaty-making process, and

- The establishment of the Australian Treaties Library, providing online access to all Australian treaty texts. ${ }^{113}$

In Germany, the treaty-making power is vested in the federal government by Basic Law, Articles 32(1), 73(1), 87(1) as "the sole institution to handle administrative affairs abroad and conduct diplomatic and consular relations." 114 The Basic Law was silent, however, on what happens if a treaty touches on subjects within the competence of the Laender - the sixteen states that comprise the Federal Republic of Germany. This gap was filled by an arrangement concluded between the Federal and Land Governments - the governments of the Laender on November 14, 1957, called the Lindau Agreement. That agreement acknowledges that there are areas of treaty-making that might be exclusively federal. These would include consular treaties, treaties on commerce and navigation, and treaties acceding to international organizations. Where treaties do touch on matters within the competence of the Laender; the agreement sets out a consultation process as follows:

- The Laender shall be informed at the earliest date possible of the proposed conclusion of such treaties so that they can make their wishes known in good time; and

- A permanent body of Laender representatives shall be set up which shall be available for consultation by the Federal Foreign Office or the competent federal ministry during negotiations on international treaties. ${ }^{115}$

113. Id. at 56

114. See Hans D. Treviranus \& Hubert Beemelmans, National Treaty Law and Practice: Federal Republic of Germany, in 27 AM. SOC’Y OF INT'L LAW, NATIONAL TREATY LAW AND PRACTICE: FranCE, GERMANY, INDIA, SwITZERLAND, THAILAND, UniTED KINGDOM 54 (Monroe Leigh \& Merritt R. Blakeslee eds., 1995).

115. Id. at 65 . 
India is a federal state but has been described as a federal structure with unitary features. ${ }^{116}$ The Constitution of India confers on the federal government "the entire field of foreign affairs." 117 The Indian Parliament "has exclusive power to legislate on foreign affairs and on all matters which bring the Union into relations with a foreign country."118 For treaty-making and implementation, the question then is one of whether legislation is required to implement the terms of a treaty and not of what level of government (i.e., either federal or state) will implement the treaty.

In contrast to India, the Confederation of Switzerland is a strong federal and highly consultative state where the executive, legislature, and Cantons are all involved in shaping external relations and treaty negotiation and implementation. 119 "[A] consensus with the cantons and all interested groups is sought before a treaty is submitted with a view to approval and ratification." 120 Mechanisms for consultation have also been set up like the Contact Committee made up of the Federal Minister of Justice and Police and members of all cantonal governments to focus on issues related to the European Union and its repercussions on Switzerland. This group has evolved into the Conference of the Governments of the Cantons that coordinates cantonal policies and views related to cross-border relations. ${ }^{121}$

Apart from these constitutional and procedural differences, the number of subnational government units that would have to adopt treatyimplementing legislation can be a significant complicating factor. Australia has only six, Canada has ten, Switzerland and Brazil each have twenty-six, India has twenty-nine, Mexico has thirty-one, and the United States has fifty (not including other subnational units such as Puerto Rico and the District of Columbia, along with the non-self-governing territories of Guam, the Virgin Islands, and American Samoa).

The greater number of federal units that must approve, the greater the likelihood that full coverage will not be achieved; that is, one or more units are likely to choose not to pass the necessary legislation or create rules that do not match well with those of other states and provinces. Even if all subunits vote to implement the treaty, the time frame under

\footnotetext{
116. K. Thakore, National Treaty Law and Practice: India, in AM. SOC'Y OF INT'L LAW, supra note 115 , at 79 . 
which this is all achieved, ceteris paribus, is longer when there are more subunits.

In the United States, despite incentives and established processes, the net result could represent something of a patchwork in terms of subnational implementation. Some agreements might be fully operational at the State level, others might be partly implemented (some States have passed the necessary legislation whereas others have not), and other treaties remain nearly or completely in non-implementation stage because States have not enacted the necessary legislation. What distinguishes these groups of outcomes and how might the suboptimal results be redressed? These are the subjects of the next sections.

\section{SuCCESS AND FAILURE In SUBNATIONAL IMPLEMENTATION}

In this Part, we examine two cases that represent the variation of subnational implementation of treaties in the United States. In the short term, and the standard adopted here, success is defined as securing adoption of legislation by States and then ratification of a treaty at the federal level. We acknowledge that a more stringent benchmark would involve an evaluation of whether such legislation was effective in meeting the goals of the treaty; unfortunately, this would require a long-term assessment of agreements and legislation that are in their nascent stage and is outside the scope of this Article.

The Hague Convention on the International Recovery of Child Support and Other Forms of Family Maintenance ${ }^{122}$ can be considered a success story in that the United States was able to deposit its ratification after each State adopted revisions to the UIFSA, a common set of standards that comply with the substantive obligations of the treaty and effectively implement them. In contrast, the Convention Providing a Uniform Law on the Form of an International Will, more commonly known as the Washington Convention, ${ }^{123}$ is an example in which subnational implementation has thus far been unsuccessful as only a minority of States has enacted suitable legislation and the agreement has not received U.S. ratification. In the Sections below, we review both of these agreements and subsequent implementation outcomes. We then conclude with some lessons concerning the conditions for success (and failure) of subnational implementation.

122. Hague Convention on International Recovery of Child Support and Other Forms of Family Maintenance, Nov. 23, 2007, S. TREATY DOC. NO. 110-21, 2955 U.N.T.S. 81.

123. Convention Providing a Uniform Law on the Form of an International Will, Oct. 26, 1973, S. TREATY DOC. NO. 99-29. 


\section{A. The Hague Convention on the International Recovery of Child Support and Other Forms of Family Maintenance}

The Hague Conference on Private International Law adopted the Convention on November 23, 2007, and on that date the United States became the first country to sign it. The instrument of ratification was deposited on September 7, 2016, and the Convention became effective in the United States on January 1, 2017. The Convention establishes "a comprehensive system of administrative cooperation among nations with respect to support and the adoption of a system for the recognition and enforcement of support orders across national boundaries." 124 Successful ratification was the culmination of an unprecedented collaborative effort involving L/PIL, the ULC, and OCSE.

In the United States, collection of child support across state boundaries is routinely and efficiently accomplished through the UIFSA, a product of the ULC. UIFSA was first promulgated in 1992 and was amended in 1996 at the time Congress was implementing welfare reform through the Personal Responsibility and Work Opportunity Reconciliation Act. This act amended Title IV of the Social Security Act, which authorizes the Child Support Enforcement Program under which federal funds are provided to the States to assist with the collection of child support, to require that States adopt the 1996 version of UIFSA in precisely the form promulgated by the ULC in order to be eligible for continued federal funding. This technique, known as conditional spending, has been approved by the U.S. Supreme Court subject to certain conditions. ${ }^{125}$

While UIFSA established a federal U.S. mechanism for the collection of child support across State lines, there was an increasing need to collect child support across international boundaries. Hence, there was a need to craft an international agreement that provided cooperation among countries, often with different legal systems. The Child Support Convention is not self-executing; rather, it is largely implemented by State law with federal law playing a crucial role. L/PIL concluded that implementation through federal law would be less than optimal because it would require the creation of a new federal bureaucracy to administer the collection of child support. Instead, UIFSA was revised in 2008 to accommodate international collections under the convention. The Senate

124. Robinson, supra note 64, at 61-62.

125. The constitutional basis for conditional spending is the Spending Clause. U.S. CONST. art. I, \ 8, cl. 1. In New York v. United States, 505 U.S. 144 (1992), the Supreme Court held that Congress cannot commandeer state legislatures and dictate that they approve a law but it can condition funding on state adoption of a law. Id.; see also South Dakota v. Dole, 483 U.S. 203, 207-08 (1987) (establishing four requirements that must be met for conditional spending to be constitutional). 
gave its advice and consent in 2010, and in 2014 federal law was amended to require that States, as a condition of continued federal funding, adopt UIFSA 2008 in precisely the form promulgated by the ULC. The instrument of ratification was deposited only after each State adopted UIFSA 2008. Full State adoption was achieved in early 2016.126

\section{A. The Washington Convention of 1973 (Recognition of International Wills)}

The Convention Providing a Uniform Law on the Form of an International Will, more commonly known as the Washington Convention, was promulgated by UNIDROIT in 1973. It deals with a common problem - the need for a will prepared pursuant to the domestic law of one country to be recognized in another country. To achieve this result, the domestic law of a country that is a party to the convention must reflect the substantive rules regarding the form (and registration) of an international will that are found in the convention. Rather than relying on choice-of-law rules to determine whether a will created under the laws of one country is effective in another, the convention created a national rule under which a will that conforms to the requirements of the convention must be recognized in each member country. A party to the agreement must introduce into its law the Uniform Law on the Form of an International Will that is attached as an Annex to the Convention. The convention permits a party to limit its effect to those subnational units that pass conforming legislation, but the United States declined to take this option. ${ }^{127}$

Although it would be possible, legally and practically, for the convention to be implemented purely at the federal level, from the standpoint of the States this is not desirable. The subject of wills has historically been reserved to the States, and the ULC and the State Department agreed that it would be best if the States themselves adopted the substantive rules of the convention. To that end, the ULC promulgated the Uniform Wills Recognition Act in 1977. The act incorporates the substantive rules of the convention into the law of an enacting State.

In many ways, this is a suitable companion case to the Hague Convention on child support in that the convention addresses a similar problem of families living across national boundaries and the associated need to coordinate legal processes and recognition of court orders. In the case of the Washington Convention, however, implementation through a

126. For more on this process and experience, see Henning, supra note 60.

127. Amelia H. Boss, The Future of the Uniform Commercial Code Process in an Increasingly International World, 68 OHIO ST. L.J. 349, 381 (2007). 
uniform act can largely be judged a failure to date. The act was adopted in fifteen States and the District of Columbia during the twenty years following its promulgation, but by the late 1990s enactment efforts had essentially ended. The reasons for the cessation of efforts is not entirely clear and may relate to the different expectations of the ULC and the State Department.

The ULC considered its efforts sufficiently successful for the convention to be submitted to the U.S. Senate. It was thought that Senate advice and consent might have encouraged other States to adopt the uniform act. At the same time, the State Department was reluctant to ask the President to transmit the convention to the Senate (anticipating that the Senate would be disinclined to act upon it) without clear assurance that the rest of the States would in fact implement its provisions by adopting the uniform act. The experience indicates the importance not only of having a clear understanding of expectations at the outset of a project but also of achieving the necessary basis for U.S. compliance with its international obligations. Both considerations were important elements in the planning for the child-support convention. The ULC revisited the international wills area in 2007 and developed a report indicating that ratification of the convention remained in the interests of U.S. citizens and that the Uniform Wills Recognition Act was still an appropriate vehicle upon which to proceed. ${ }^{128}$ This gained enactment by three more States and the U.S. Virgin Islands in 2009 and 2010 but there has been no further activity since then.

\section{A. Lessons for Successful Subnational Implementation of Treaties}

How did two very similar treaties produce divergent outcomes in terms of subnational implementation by States? It wasn't necessarily that one treaty was in the interests of the States and the other less so. Both addressed a clear problem stemming from families located in different parts of the world: the validity of legal rulings and documents across national borders. Generally, the United States would not have agreed to the conventions had there not been strong and clear perceived benefits. The difference between the two cases must lie with other conditions.

The clearest difference was the financial incentives for the States. Federal legislation made adoption of UIFSA 2008 a condition of continued federal funding of child support recovery efforts. Thus, prompt action by a State was in its interest; a failure by any State to act quickly

128. Memorandum from David English, Executive Director, Joint Editorial Board for Uniform Trust and Estate Acts to the Annual Meeting of the National Conference of Commissioners on Uniform State Laws (July 31, 2007) (on file with authors). 
would result in significant penalties. It is perhaps not surprising, therefore, that the Hague Convention was successful in finding its way into the legislation of all States. By contrast, adherence to the Washington Convention offered no similar (financial) incentive; indeed, many States did not seem to view it as providing a particular benefit (or of resolving a particular problem), and therefore saw no cost to inaction.

These differences had a precipitating and reinforcing effect on another key factor: the speed of the subnational implementation process. The financial incentives reduced the uncertainty for a given State that others would adopt the law and therefore it was easier to take the risk of adopting new legislation knowing that others were highly likely to follow. The rapid succession of State adoptions also created a cascading effect that not only further sped up the process but increased the probability of each successive adoption. The Convention on Wills offered no such advantage and the movement toward adopting the relevant uniform law suffered over time. States became increasingly reluctant to change their laws because of their doubts about the ultimate ratification of the convention.

In the case of child support, adoption of the uniform legislation was also relatively easy for State legislatures because the Convention's provisions fit snugly with many existing processes and provisions. For example, the Convention recognizes U.S. due process. In addition, the provisions allow for the challenge of a foreign support order that did not include a process involving notice and a hearing. Any foreign orders had to comply with U.S. jurisdictional rules. The treaty also requires countries to provide free legal assistance in the recognition and implementation of existing child support orders, something that is already present in the United States. These were reassuring provisions to lawmakers who feared foreign laws and practices being imposed on Americans. In 2016, the Department of Health and Human Services reported 15.6 million individuals served by its Office of Child Support Enforcement and \$33 billion in child support payments collected now, including a portion coming from outside the United States. ${ }^{129}$

The Convention dealing with child support is the only fully successful case of U.S. subnational implementation of an international agreement. Despite the ULC's federal-State endeavors, it is not clear how often the conditions for success will be duplicated with respect to other treaties.

\section{Are Self-Executing Treaties the SOlution?}


The analyses above suggest that relying on subnational implementation, especially in the United States, can be a risky strategy. Is there a better way to avoid this step in ensuring the implementation of international treaties?

One possible solution is to adopt treaties on a self-executing basis, so that they automatically become part of national law without the need for enacting legislation at either the national or subnational levels. As we have seen with the Vienna Convention on Consular Relations, however, when treaty obligations are not transformed into directly enforceable local law, implementation can be spotty and incomplete. Furthermore, this is not the common approach in recent practice, at least in terms of replacing current U.S. law, even without considering whether federalism issues arise. 130

In areas in which self-executing agreements are practical, does adoption on a self-executing basis necessarily solve the problems noted above? As with the previous Part, we offer two examples of self-executing agreements, one a success in obviating the need for subnational implementation (Convention on the Assignment of Receivables in International Trade) ${ }^{131}$ and the other that has been suboptimal in having its intended effect at the subnational level (UN Convention on Contracts for the International Sale of Goods). ${ }^{132}$ We end this Part with a cautionary note about the limitations of self-executing agreements as an alternative to subnational implementation.

\section{A. Convention on the Assignment of Receivables in International Trade}

A lender that takes as security an assignment of its borrower's receivables must be certain that its right to collect from debtors will be protected against third parties, including another lender with an interest in the receivables as collateral, a buyer of the receivables, an unsecured creditor of the borrower, and most notably an insolvency representative (trustee in bankruptcy in the U.S. system). The same need exists if a person's receivables are sold, either to a factor or as part of a securitization program. The buyer must be protected from the same cast of characters. ${ }^{133}$

130. Stewart, supra note 8 , at 229

131. U.N. Convention on the Assignment of Receivables in International Trade, Dec. 12, 2001, S. TREATY DOC. NO. 114-7.

132. U.N. Convention on Contracts for the International Sale of Goods, Apr. 11, 1980, S. TREATY DOC. NO. 98-9, 1489 U.N.T.S. 3.

133. As used in this Article, "receivables" means contractual rights to the payment of money, and "assignment" includes both the creation of a security right in receivables as collateral for an obligation and the outright sale of receivables. "Assignor" means both a person that grants an interest in receivables as collateral for value received (e.g., a loan) and a person that sells receivables; and 
Many countries have sophisticated laws governing a lender's or buyer's priority rights. In the United States that law is Article 9 of the Uniform Commercial Code ("UCC"), which is a joint product of the ULC and the American Law Institute ("ALI"). In Canada, it is the Personal Property Security Act ("PPSA"). The UCC and the PPSA are State and provincial, rather than federal, law, and an assignee must have certainty as to which State's or province's law governs priority rights. Under both regimes, this certainty is provided by choice-of-law rules designating the law of the assignor's location as the governing law. The choice-of-law rules work well for a domestic transaction, but there is a risk in an international transaction that a court will choose the law of a country that does not have a robust set of rules protecting the interests of assignees.

The purpose of the Convention on the Assignment of Receivables in International Trade is to provide certainty with regard to the governing law in international transactions. It was drafted by the U.N. Commission on International Trade Law and approved by the U.N. General Assembly on December 12, 2001. The Convention has been adopted by Liberia and signed by Luxembourg, Madagascar, and the U.S. (on December 30, 2003). It must be adopted by five nations to enter into force. The U.S. Senate Committee on Foreign Relations held hearings on the treaty in March 2018 and recommended it favorably for advice and consent to the full Senate on September 12, 2018. The Senate gave its advice and consent on January 2, 2019. The United States deposited the instrument of ratification on October 15, 2019.

The Convention excludes from its scope transactions in securities, derivatives and other financial assets, assignments of deposit accounts, and assignments of claims under letters of credit and independent guaranties.

It has rules protecting the holders of negotiable instruments and assignees of certain real estate lease receivables. Because of these restrictions, the Convention primarily applies to assignments of trade, loan, and similar commercial and consumer receivables arising in assetbased lending, factoring, securitization, and project finance transactions.

The Convention applies only if the assignment or the receivable is "international," meaning that the assignor and assignee are in different countries (international assignment) or the assignor and the debtor are in different countries (international receivable). Also, in all cases the assignor must be in a country that has adopted the Convention. For the debtor's rights and obligations to be affected, the debtor must be located in a

"assignee" means a person that acquires an interest in receivables as collateral for an obligation and a buyer of receivables. The person that owes payment to the assignor is called the "debtor." "Convention" means the United Nations Convention on the Assignment of Receivables in International Trade. 
country that has adopted the Convention or the contract giving rise to the receivable must be governed by the law of a country that has adopted it.

The Convention was drafted at a time when UCC Article 9 was undergoing wholesale revisions, and the State Department appointed to its delegation individuals who were involved in the Article 9 revision process. Issues raised in negotiating the Convention were considered by the Article 9 drafting committee, and issues raised in the Article 9 process were considered in negotiating the Convention. This had the salutary effect of creating significant harmony between the Convention and domestic U.S. law. The main differences between the Convention and Article 9 relate to a small subset of the rules that determine which jurisdiction's law governs an assignee's rights in a receivable.

A study to determine whether ratification of the Convention would be too disruptive of domestic law was undertaken by a committee jointly approved by the ULC and ALI, and it was joined by representatives of the Uniform Law Conference of Canada and the Uniform Law Center of Mexico. There was some consideration of simply harmonizing the laws of the three countries with respect to the assignment of receivables, but eventually it was determined that each country should become a party to the Convention. Consideration was given to amending Article 9 to reflect the Convention's choice-of-law rules for international assignments and provisions to that effect were drafted, but the idea was abandoned because of concern that gaining enactment in the more than fifty U.S. jurisdictions would be difficult and time-consuming and therefore might be disruptive of ongoing commercial transactions.

After making the tentative decision to recommend ratification to the Senate, the committee tested the market for the Convention by holding open symposia, jointly sponsored by the State Department's Office of Private International Law, in New York and Los Angeles at which the rules of the Convention were explained in the context of specific hypotheticals. In addition to representatives of a number of major law firms, the symposia were attended by representatives of major financial institutions such as Bank of America, Citicorp, GMAC, JPMorgan Chase, Merrill Lynch, PNC Bank, UBS, Wachovia, US Bank, and Standard and Poor's. The overwhelming reaction was that the choice-of-law differences were manageable and that ratification was in the best interests of the United States. ${ }^{134}$

The committee ultimately prepared a draft of a potential report from the Senate Foreign Relations Committee to the full Senate recommending

134. See NAT'L CONF. COMMISSIONERS ON UNIFORMST. LAws, REPORT OF THE COMMITTEE TO HARMONIZE NORTH AMERICAN LAW WITH REGARD TO THE ASSIGNMENT OF RECEIVABLES IN INTERNATIONAL TRADE CONVENTION 5-6 (2007). 
ratification subject to certain declarations and understandings designed to minimize the differences between the Convention and Article 9.135 These declarations and understandings were crucial for the Convention to function in harmony with domestic U.S. law, and they were the most important part of the committee's work. The committee also prepared a draft report containing an article-by-article comparison of the Convention and Article 9 for potential submission by the State Department to the President. It was understood by all concerned that the Convention would be self-executing.

Although this meant no new State implementing legislation because existing law was adequate, the effect of the Convention on State law played a significant role in the drafting of the Convention and in the ultimate decision to recommend ratification to the U.S. Senate. Without the work of the joint ULC-ALI committee, it is not clear that the Convention could have moved forward towards ratification. This is perhaps the best available model for future State-federal cooperation.

\section{A. Convention on the International Sale of Goods}

The 1980 U.N. Convention on the International Sale of Goods ("CISG") serves an important function in trans-border trade by providing a uniform, internationally agreed-upon regime for ordinary commercial transactions. Specifically, it addresses the legal rules governing the formation of contracts for the international sale of goods, the respective obligations of the buyer and seller, the passage of risk, and remedies available to both parties in case of breach of contract. It applies to sales contracts between private parties whose places of business are in different states party to the treaty. The aim is to promote certainty in cross-border business-to-business dealings by displacing differing (and often conflicting) domestic rules that might otherwise be applicable to the parties and their contract. Some consider it one of the international community's most ambitious and successful efforts to promote efficiency and sustained growth of international trade. ${ }^{136}$

The United States ratified the CISG in 1986 and it became effective domestically on January 1, 1988. Even though the treaty had broad support in the U.S. business community, its ratification proved controversial for several reasons, among them: (i) U.S. law governing

135. S. EXEC. REP. NO. 115-7 (2018).

136. As of the time of this writing the CISG has been adopted by 93 countries. Status: United Nations Convention on Contracts for the International Sale of Goods, UNCITRAL, https://uncitral.un.org/en/texts/salegoods/conventions/sale_of_goods/cisg/status (last visited Jan. 1, 2020). 
contractual relationships in the United States is almost entirely State (rather than federal) law, even though a measure of uniformity has been achieved through State adoption of Article 2 of the Uniform Commercial Code; (ii) the CISG's provisions are often inconsistent with the relevant provisions of Article 2, and (iii) there was considerable reluctance to permit the federal government to intrude into the traditional role of States in the field of ordinary commercial transactions by "federalizing" commercial law.

Rather than implementing the treaty through federal legislation, the choice was made to adopt it on a self-executing basis, so that (by virtue of the Supremacy Clause), to the extent it applies in a given commercial context, it does so directly and overrides inconsistent State law, including UCC Article 2, unless the contracting parties explicitly opt out. By definition, enforcement of the CISG would fall primarily to the judiciary since the treaty would typically come into play when the parties could not resolve a dispute and had submitted it to litigation. All U.S. courts federal and State - would therefore be bound to apply the CISG to issues raised by international sales contracts covered by the treaty. Since the treaty would apply only in cases of disputes under international transactions, federal regulation of which falls within Congress's authority under the Commerce Clause, the intrusion into a traditional area of State authority was relatively mild.

The impact of the CISG has indeed been somewhat limited. One reason is that contracting parties (and not infrequently the courts considering their dispute) are often unaware that the treaty applies to the particular transaction. ${ }^{137}$ As a self-executing treaty, the CISG became federal law directly, without being "codified." As a result, lawyers and judges often overlook it in their research and are inclined to default, mistakenly, to the relevant State law in their analyses. Moreover, even when they are aware that the CISG applies, they frequently struggle with the different terminology used in the treaty and the comparative lack of interpretive precedent in prior case law, turning in such cases to otherwise applicable State law (with which they are more familiar). This phenomenon, which is unfortunate but perhaps inevitable, is sometimes described as the "homeward trend." 138

137. One of the motivations in enacting the Uniform International Wills Act was to make the provisions of the Washington Convention on Wills visible to state judges and practitioners who would normally only consult compilations of state law rather than federal law or international law. See UNIF. L. COMM’N, UNIFORM WILLS RECOGNITION ACT 4 (2009).

138. Harry Flechtner, Article 79 of the United Nations Convention on Contracts for the International Sale of Goods (CISG) as Rorschach Test: The Homeward Trend and Exemption for Delivering Non-Conforming Goods, 19 PACE INT'L L. REV. 29 (2007). 
One recent empirical study indicates that experienced U.S. attorneys often advise their clients to opt out of the CISG, which the Convention permits. John Coyle's dataset indicates that "past surveys of U.S. lawyers dramatically overstate the extent to which the CISG has gained acceptance within the U.S. legal community"139 and "highlight the potential unfairness of requiring unsophisticated U.S. companies to litigate international contract disputes under a set of treaty rules that are routinely avoided by their more sophisticated brethren."140

The CISG experience demonstrates both the difficulties that can arise when the subject-matter of a treaty is primarily State (rather than federal) law and the often-overlooked shortcomings of the "self-execution" approach to treaty implementation. It also suggests that leaving treaty implementation entirely to the courts (often touted as an optimal "control mechanism") has some drawbacks when it comes to ensuring consistency of interpretation and application.

\section{A. Self-Executing Treaties and Their Limitations}

At least in the abstract, it would seem that making a treaty selfexecuting would be far better than depending on separate legislative enactments by fifty States plus the District of Columbia, Puerto Rico, Guam, and the Virgin Islands. Nevertheless, empirically, there are a number of caveats or limitations to this.

First, the idea of a purely self-executing agreement might be illusory. As Stewart notes, most treaties that are described as self- executing are not and in fact are legislatively implemented. ${ }^{141}$ With the rise of multilateral treaties has come greater complexity, not only because they need to be broadly applicable to many parties, but also because the subjects of treaties are now more intricate and multifaceted. Additional implementing legislation at the national and/or State level becomes essential.

Second, the process of self-execution may work better when the primary responsibility for execution and compliance lies at the federal, rather than State, level although this was not the outcome with respect to CISG. There is also less likely to be political pushback at the State level if the subject of the treaty is not highly salient there. Thus, choosing the selfexecuting option may be best when such implementation occurs more at the federal than the subnational level.

139. John F. Coyle, The Role of the CISG in U.S. Contract Practice: An Empirical Study, 38 U. PA. J. INT’L L. 195, 196 (2016).

140. Id.

141. Stewart, supra note 8, at 232, 271. 
Third, and as the CISG example indicates, there is no guarantee that self-executing agreements will have their intended effect at the State level. In some areas, it appears that treaty law is not applied, not because of opposition but because of ignorance on the part of State lawyers and judges. Even generally, Stewart notes that the empirical evidence that selfexecution increases compliance with international obligations is lacking. ${ }^{142}$

Finally, implementing treaties directly through self-execution rather than legislation does not necessarily speed up the process of getting the law onto the books. The Receivables Convention was negotiated in 2001 and, seventeen years later, has not been ratified by the United States, much less entered into force even with an unusually low five-party threshold for that entry.

\section{CONCLUSIONS AND IMPLICATIONS}

Countries want the treaties they negotiate to be effective in order to reap the benefits associated with them. But successfully negotiating a treaty and effectively implementing its provisions are different undertakings, even if ratification is assured. Some agreements require additional implementing legislation at the national and subnational level to give them the desired legal effect within those jurisdictions. This is part of a broader concern facing international law: rules may be adopted, but the legal operating system or infrastructure cannot ensure that they take effect. Subnational implementation may fill in some operational gaps, but this assumes that countries can and will follow through with appropriate legislative actions. For a number of reasons discussed above, this does not always occur.

The problem is more acute for a complex federal system like that of the United States where the treaty-making power clearly resides with the federal government, but where implementation requires either a political decision to pre-empt State law or separate legislative action by the constituent States. Over the decades, as multilateral treaty-making has moved increasingly into subjects covered by State law, the federal government has actively reached out to include representatives and experts representing State interests on treaty negotiating delegations.

Regular consultation has also been instituted through bodies like the U.S. Department of State's Advisory Committee on Private International Law consisting of members from private organizations, including bar associations, and representatives of federal and State agencies and courts. The Advisory Committee also organizes study groups to provide advice 
on specialized subjects of private international law.143 Organizations active on the Advisory Committee are the American Branch of the International Law Association, the American Law Institute, the American Society of International Law, the Section of International Law of the American Bar Association, and the ULC. 144 Of this list, only the ULC has a primary focus on State interests.

As we have seen, failure to pass implementing legislation has a number of consequences. First, if the prospects of subnational implementation are dubious or likely to be incomplete (e.g., if a large number of U.S. States are unlikely to adopt the necessary legislation), the federal government might be reluctant to negotiate or sign a given agreement even if there are benefits for the country; there are reputational costs in accepting an agreement if it cannot guarantee implementation (and even in negotiating actively but then failing to adhere to a treaty). Similarly, foreign governments are likely to be reluctant to be a party with the United States if there is no credible commitment that subnational implementation will occur.

A second scenario is that the United States signs an agreement but is unable to ratify it because of an inability to secure implementing legislation. This would result in no benefits from the agreement since other treaty parties would not be obligated vis-à-vis the United States to follow the agreement provisions.

Third, and a variation of the previous situation, the United States might ratify the treaty, but still be unable to ensure State-level adoption. As has been true in several cases noted above, the U.S. government could be held responsible in international courts for performance failure or breach of its international obligations even if the federal government cannot compel State governments to cooperate. This issue arises in other countries with federal systems, but is more pronounced for the United States because the number of subnational entities makes adherence through normal State legislative processes very difficult.

How might states avoid the deleterious consequences above when subnational implementation of treaties fails? This study examined practice in the United States on subnational implementation of treaties, describing the process and examining one case of success and one of failure. Clearly, the ULC is a major asset for the United States as it provides a familiar, respected, and used mechanism for advising and drafting legislation that

143. For information about the Advisory Committee on Private International Law, see Advisory committee on Private International Law, U.S. DEP'T OF STATE, https://www.state.gov/advisorycommittee-on-private-international-law/ (last visited Jan. 1, 2020).

144. See Committee Members, Meetings, and Advisory Reports, GENERAL SERviCES ADMIN., https://www.facadatabase.gov/FACA/FACAPublicViewCommitteeDetails?id=a10t0000001gzpO AAQ (last visited Jan. 1, 2020). 
can then be adopted by fifty States if they so choose. This was the case with the 2008 UIFSA that included the provisions of The Hague Convention on the International Recovery of Child Support and Other Forms of Family Maintenance.

It is hard to imagine any chance of coordinated legislative action at the State level without such a body. Even so, as we saw with the 1973 Convention Providing a Uniform Law on the Form of an International Will (the Washington Convention) success is far from assured with respect to international agreements although the ULC produced a Uniform Law on the Form of an International Will that was annexed to the Convention. ${ }^{145}$ The ULC has a record of success that includes more than three hundred instances of uniform law adoption, but these deal almost exclusively with purely internal or domestic concerns and not international treaties. At the same time, international efforts to regulate or to harmonize activities are increasing in areas of domestic and State law within the United States. These include "matters relating to children and families; dispute resolution (including international arbitration and mediation); judicial cooperation (including the recognition and enforcement of foreign judgments); insolvency; finance and banking; secured transactions; contract law; electronic commerce; and wills, trusts, and estates." 146

How might the prospects for subnational implementation of treaties be improved? This study reviewed the option of self-executing treaties, which would obviate the need for subnational implementation. Nevertheless, we have seen the limitations to this approach, not the least of which were Constitutional restrictions and the possibility that State legal officials would unwittingly ignore relevant treaty obligations as appears to have occurred in the case of enforcing the provisions of the Convention on the International Sale of Goods. This leads us to circle back to see what we might conclude from the ULC driven process of consultation and drafting.

Drawing conclusions from a single case of success is risky, but we can also learn from the failures that have occurred. Generally, subnational implementation is most likely when the following conditions are met:

- Where State laws already largely conform to what a treaty provides; that is, where existing subnational law is adequate to meet the treaty's requirements. This exists in some areas based on past ULC successes within a purely

145. From the time the Uniform Wills Act was promulgated in 1977 to 2019, only 20 jurisdictions enacted it (18 States, the District of Columbia, and the U.S. Virgin Islands). See supra note 137.

146. Stewart, supra note 8 , at 280; supra note 138. 
domestic context, and thus any necessary adjustments based on the treaty should be more manageable. If such laws are already in place, one might question the need for additional action at the State level, specifically to implement a treaty, but such implementation ensures that the same processes operate for U.S. citizens and companies in other countries under an international agreement.

- Early involvement of the ULC and other domestic stakeholders in the treaty negotiation process. This occurs in some cases, but not all. Such involvement could allow U.S. negotiators to craft treaty provisions and adjust bargaining positions that most closely correspond to State law or which have the best prospects for later adoption by States, while still having the treaty serve U.S. interests. It is important in most cases for the United States government to involve domestic constituencies during the negotiations, in order to get a full understanding of the problem to be solved, how it's handled in domestic law and practice, and what the legal and political limits might be. Still, there is never a guarantee that the United States can get all it wants or needs during a treaty negotiation. In an international community of 194 independent states, with varying legal systems, unanimity is rarely achievable and compromise is almost always necessary, requiring some adjustment on the part of the constituent States of the United States.

- Delay ratification until after subnational legislative adoption has taken place. This approach ensures that domestic implementation is effective and that the United States doesn't make commitments internationally that are not reflected in individual State practice, which can take a long time to reach completion. In the meantime, U.S. interests are not served by the treaty as has been the case, for example of the Wills Convention.

The structure of the U.S. federal system poses challenges with respect to ratification and implementation of treaties, but is the United States doomed to suboptimality, i.e. signing treaties that it does not ratify? Is it so bad that only some U.S. States adopt uniform acts in support of treaties (i.e., is there a significant risk that lack of uniform implementation would pose a substantial likelihood that the United States would be found in violation of its treaty obligations)? Alternatively, is it so bad that the 
United States cannot become party to many agreements because it cannot figure out how to assure effective domestic implementation?

Because not all States had adopted the necessary laws, the more common outcome with efforts to use uniform acts to implement treaty obligations is enactment in some number of States but the United States not ratifying the agreement. Julian $\mathrm{Ku}$ provides the following list of examples:

[T] he Uniform Probate Code, adopted in eighteen [U.S.] states, also contains provisions "in harmony with" the Hague Convention on the Conflicts of Laws Relating to the Form of Testamentary Dispositions. The Uniform Trust Code, adopted in nineteen states, has a provision allowing a settlor to designate the governing law, and in the absence of such designation, providing choice of law rules is "consistent with and was partially patterned on the Hague Convention on the Law Applicable to Trusts and on their Recognition." And the Uniform Child Custody Jurisdiction and Enforcement Act, adopted in forty-six states, provides that a custody determination can be registered without any request for enforcement. As the official comment to this section notes, this provision is required by the Hague Convention on Jurisdiction, Applicable Law, Recognition and Cooperation in Respect of Parental Responsibility and Measures of the Protection of Children. ${ }^{147}$

Because the primary objective of many of these private international law conventions is to harmonize and to coordinate important practices around the world, a question can be raised as to the value of efforts, such as the drafting of uniform acts, to harmonize various legal regimes and to minimize differences. Is the effort of producing a study and uniform or model act that might be adopted only by some jurisdictions still valuable as a step towards helping to conform U.S. and international practices? After all, the time it takes to negotiate a treaty and to adopt subsequent implementing legislation might change the political circumstances that initially compelled a project to completion. As we have seen with the Wills Convention, failure to achieve greater enactment may not stem from opposition. It simply may no longer be a high enough priority to carry the project over the finish line towards levels of enactment that would result in the U.S. completing the treaty ratification process. This also suggests

147. Julian G. Ku, The Crucial Role of the States and Private International Law Treaties: A Model for Accommodating Globalization, 73 MO. L. REV. 1063, 1067-68 (2008). 
that the United States government may want to ensure that the relevant domestic constituencies actually believe a treaty is needed before engaging in the treaty- making process and that States will subsequently enact the necessary legislation to make eventual ratification of an international agreement by the United States possible.

Does the close cooperation between those negotiating the treaties and those who have to implement them at the State level help to harmonize practice even if formal acts are not adopted and treaties not ratified? As noted above, the adoption of international standards is not confined to States; municipalities have also adopted measures to implement treaty provisions. As Boss suggests: "These may be considered illustrations of domestic attempts at international harmonization of the law rather than state implementation of international treaty obligations."148

Such piecemeal adoption of international treaty obligations complicates the international legal landscape but seems unavoidable given the political structures in place and the kinds of subject matter now subject to international regulation. Although such an approach might make the advantages and conveniences of these treaties available to individuals in the jurisdictions that accept these provisions, it still places U.S. nationals and interests at a disadvantage outside the United States where such piecemeal adoption may not be recognized.

The interests of constituent States of the United States will necessarily be involved in treaty implementation because of the nature of the issues now subject to international regulation. In order to maintain their prerogatives and protect their citizens and interests, States can act through processes they control and influence or be subject to federal legislation should their failure to do so damage U.S. interests. We have seen where and how cooperation between the federal and State governments can take place. Only time will tell if these experiences and networks will lead to increased levels of cooperation and higher levels of U.S. participation in multilateral treaties. This Article shows how and where cooperation has occurred and how such cooperation might provide an additional pathway towards treaty implementation in the United States. 